\title{
MANAGING CAPITAL FLOWS IN ASIA: AN OVERVIEW OF KEY ISSUES
}

James Villafuerte and Josef T. Yap

NO. 464

November 2015
ADB ECONOMICS WORKING PAPER SERIES 
ADB Economics Working Paper Series

\section{Managing Capital Flows in Asia: An Overview of Key Issues}

James Villafuerte and Josef T. Yap

No. 464 | November 2015
James Villafuerte (jamesvillafuerte@adb.org) is Economist from the Asian Development Bank. Josef T. Yap (josef.t.yap@gmail.com) is Professorial Lecturer at the School of Economics, University of the Philippines.

The authors are grateful to Michael Angelo Cokee, Ryan Jacildo, and Lee Marie Miranda for excellent research support. 
Asian Development Bank

6 ADB Avenue, Mandaluyong City

1550 Metro Manila, Philippines

www.adb.org

(C) 2015 by Asian Development Bank

November 2015

ISSN 2313-6537 (Print), 2313-6545 (e-ISSN)

Publication Stock No. WPS157761-2

The views expressed in this paper are those of the authors and do not necessarily reflect the views and policies of the Asian Development Bank (ADB) or its Board of Governors or the governments they represent.

ADB does not guarantee the accuracy of the data included in this publication and accepts no responsibility for any consequence of their use.

By making any designation of or reference to a particular territory or geographic area, or by using the term "country" in this document, $A D B$ does not intend to make any judgments as to the legal or other status of any territory or area.

Note: In this publication, "\$” refers to US dollars.

The ADB Economics Working Paper Series is a forum for stimulating discussion and eliciting feedback on ongoing and recently completed research and policy studies undertaken by the Asian Development Bank (ADB) staff, consultants, or resource persons. The series deals with key economic and development problems, particularly those facing the Asia and Pacific region; as well as conceptual, analytical, or methodological issues relating to project/program economic analysis, and statistical data and measurement. The series aims to enhance the knowledge on Asia's development and policy challenges; strengthen analytical rigor and quality of ADB's country partnership strategies, and its subregional and country operations; and improve the quality and availability of statistical data and development indicators for monitoring development effectiveness.

The ADB Economics Working Paper Series is a quick-disseminating, informal publication whose titles could subsequently be revised for publication as articles in professional journals or chapters in books. The series is maintained by the Economic Research and Regional Cooperation Department. 


\section{CONTENTS}

TABLES AND FIGURES

ABSTRACT

$\begin{array}{lll}\text { I. } & \text { BACKGROUND } & 1\end{array}$

$\begin{array}{ll}\text { II. INTRODUCTION } & 2\end{array}$

III. THEORETICAL AND POLICYISSUES 2

A. $\quad$ Determinants of Capital Flows 2

B. Advantages of Greater Capital Mobility 4

C. Drawbacks of Greater Capital Mobility 4

D. $\quad$ Some Empirical Evidence $\quad 6$

$\begin{array}{ll}\text { E. Policy Issues } & 7\end{array}$

IV. CAPITAL FLOWS IN ASEAN+3

A. Degree of Capital Account Openness 12

B. $\quad$ Magnitude of Capital Flows 13

C. Composition 14

D. Capital Flow Wave Pattern: Surge, Stop, Withdrawal, and Retrenchment 15

E. Impact of Capital Flows $\quad 17$

V. $\quad$ CAPITAL FLOWS: RECENT TRENDS IN ASEAN+3 22

A. Drivers of Regional Capital Flows (Quantitative Easing Tapering Period) 22

B. $\quad$ Analysis of Global and Regional Spillover and Contagion Effects 27

$\begin{array}{ll}\text { VI. POLICY RECOMMENDATIONS } & 30\end{array}$

A. Increase Foreign Direct Investment and Its Share in Capital Inflows 31

B. Macroprudential Policies $\quad 32$

C. Capital Controls 33

D. Exchange Rate Coordination Has to Be Reconsidered 34

E. Regional Financial Cooperation $\quad 35$

$\begin{array}{ll}\text { APPENDIXES } & 37\end{array}$

$\begin{array}{ll}\text { REFERENCES } & 41\end{array}$ 


\section{TABLES AND FIGURES}

\section{TABLES}

1 Summary of Policy Measures

2 Total Stock of Assets and Liabilities, ASEAN+3 13

3 Magnitude of Capital Flows, ASEAN+3 14

$4 \quad$ Foreign Exchange Reserves Net of Gold, ASEAN+3 19

5 M2 Year-on-Year Growth, ASEAN+3 20

6 Inflation, ASEAN+3 21

7 Drivers of Capital Flows, Panel Data Regression Using Five Asian Economies 24

$8 \quad$ Shock and Volatility Spillovers 27

$9 \quad$ Shock and Volatility Persistence $\quad 28$

10 Vector Autoregression Analysis: Share of Growth Variance Due to Each Economy 29

\section{FIGURES}

$1 \quad$ Coping with Surges in Capital Inflows: Macroeconomic and Considerations Prudential 11

2 Degree of Openness of Capital Account, ASEAN+3 12

3 Financial Inflows, ASEAN+3 15

4 Surge-Stop Episodes in Capital Inflows, Selected Asian Economies 16

$5 \quad$ Surge-Stop Episodes in Capital Outflows, Selected Asian Economies 17

6a Real Effective Exchange Rates, ASEAN 18

6b Real Effective Exchange Rates, + 3 Economies and Hong Kong, China 18

$7 \quad$ Stock Price Indexes, ASEAN+3 22

$8 \quad$ Asian Financial Markets, Average Day-on-Day Changes on Quantitative Easing

9 Global Interest Rate Expectations versus Global Risk Perception 25 


\begin{abstract}
Global capital flows into emerging markets, including those in Asia, continue to be volatile. These capital flows generate both benefits and costs. The latter are associated with episodes of currency and banking crises like the 1997 Asian financial crisis and the 2008 global financial and economic crisis. Policy responses can be implemented to minimize the costs. At the same time, policy responses should vary depending on whether "pull" factors or "push" factors dominate the capital flows. Data show that the main impact of capital flows on economies of East Asia is reflected in real effective exchange rates, equity prices, and accumulation of foreign exchange reserves. If "pull" factors are dominant, policy makers should allow real exchange rates to appreciate in the long-term. Three broad categories of macroeconomic measures are available to countries facing surges of capital inflows, if they are not willing to allow the nominal exchange rate to appreciate: (i) sterilized intervention, (ii) greater exchange rate flexibility, and (iii) fiscal tightening (preferably through expenditure cuts). However, all of them have major drawbacks. Instead, capital controls or, more generally, macroprudential policy can be considered. Other policy recommendations include measures to encourage foreign direct investment, as this type of capital flow is more stable and beneficial; exchange rate coordination to reduce the adverse impacts of currency appreciation on the global competitiveness of domestic firms; and regional financial cooperation, particularly in the development of local bond markets. Recent data show the adverse impact of Quantitative Easing tapering on Asian economies. This is verified by econometric results showing the strong linkages between the United States bond markets and those in Asia. These findings enhance the role of macroprudential policy, which can be implemented in the context of regional cooperation in order to reduce negative spillovers across economies in Asia.
\end{abstract}

Keywords: capital flows, exchange rates, regional cooperation, volatility

JEL Classification: F31, F32, F36 


\section{BACKGROUND}

Economic performance of the Association of Southeast Asian Nations plus the People's Republic of China (PRC), Japan, and the Republic of Korea (ASEAN+3) countries are highly sensitive to the global financial environment. The first half of 2013 started with another quarter of capital inflows into the region. Coupled with relatively sustained growth of the ASEAN+3 economies, the loose monetary policies of advanced economies had been driving money into the region. However, both of these push and pull factors gradually lost strength in the second quarter. Following Chairman Bernanke's statement on possible tapering of the United States (US) quantitative easing (QE) in May 2013, investors have become increasingly concerned about an exit from easy monetary conditions, notwithstanding the announcement of an aggressive expansionary policy in Japan. Lack of clarity of in the timing and process has resulted in volatile flows of capital, with and many of the ASEAN+3 economies experienced outflows of capitals from the bond and equity markets, along with rising risk premiums.

To date, the policy lever in the US has normalized and capital flows are returning to the region. Yet the global economy still faces a number of uncertainties in the coming years. One immediate uncertainty is the evolution of monetary and fiscal policy in advanced economies and its impact on the global economy. Another uncertainty is that all major economies-the US, the European Union (EU), the PRC, Japan, and emerging economies collectively-are all undergoing major structural adjustments 5 years after the global financial crisis (GFC). The impact of these structural adjustments is also uncertain. Global uncertainties will affect global liquidity conditions, and subsequently create volatile capital flows to and from ASEAN+3.

This paper is the regional overview of a study that aims:

(i) to get a better understanding of the dynamic nature of global liquidity-the factors driving global liquidity as well as the transmission channels to the ASEAN+3 markets; and

(ii) to take stock of lessons learned with respect to impacts, policies, and implications of volatile capital flows on the ASEAN+3 economies.

(iii) Based on lessons learned, the next task is to design policy frameworks and guidelines to deal with future challenges in managing capital flows.

For this regional overview, we are interested in identifying the primary transmission channels of global liquidity into the ASEAN+3 economies. Selected questions to be discussed in this section include:

(i) Have all different episodes of global liquidity expansion affected the regional economies of the ASEAN+3?

(ii) What were the transmission channels of these shocks (i.e., bank lending, portfolio flows)?

(iii) Have there been consistent transmission channels across different episodes of global liquidity expansion? 


\section{INTRODUCTION}

Global capital flows remain an important issue in international finance. In the aftermath of the 2008 global financial and economic crisis, capital flows to emerging countries surged again. There have been similar episodes in the past 3 decades, including one that culminated in the 1997-1998 East Asian financial crisis (AFC). Meanwhile, the GFC was followed by an unprecedented easing of monetary policy by both the US and Japan. This contributed to concerns about volatile capital flows and the stability of the global financial system.

The problems that have emerged in the various episodes are like a refrain in a song: appreciating currencies that could lead to exchange rate overshooting, pressure on asset prices, which can result in bubbles that amplify financial fragility and crisis risk, and the possibility of overheating, resulting in inflation. The macroeconomic difficulties spawned by the volatility of capital inflows have elicited various policy responses (IMF 2007):

"Whereas some countries have let exchange rates move upward, in many cases the monetary authorities have intervened heavily in foreign exchange markets to resist heavy currency appreciation. To varying degrees, they have sought to neutralize the monetary impact of intervention through sterilization, with a view to forestalling an excessively rapid expansion of domestic demand. Controls on capital inflows have been introduced or tightened, and controls on outflows eased, to relieve upward pressure on exchange rates. Fiscal policies have also responded-in some cases, stronger revenue growth from buoyant activity has been harnessed to achieve better fiscal outcomes, although in many countries rising revenues have led to higher government spending."

As a result of this type of policy responses, the typical macro configuration in emerging markets in Asia after the AFC was slower growth, less investment, current account surpluses replacing deficits, and a successful management of the exchange rates to keep exports competitive, involving a large buildup in foreign exchange reserves (Grenville 2012).

This paper looks into the experience of the ASEAN+3 economies with regard to capital flows during the period 1990 to the present. Emphasis will be on the last 3 years (2011-2013) since previous work has covered the earlier period adequately (e.g., Kawai and Lamberte 2010). The next section will review the major issues with regard to capital flows. Section III will present data that show trends of capital flows in ASEAN+3 and their impact for the period 1990-2013. This will be followed by a discussion on the economic environment in ASEAN+3 based on recent indicators from the Asia Regional Integration Center. The last section deals with policy issues.

\section{THEORETICAL AND POLICY ISSUES}

\section{A. Determinants of Capital Flows}

The surge in capital flows to emerging market economies in the past 30 years is a reflection of the rapid expansion and integration of international capital markets that had been driven by economic policy and structural changes, and technological factors. The latter refer to revolutionary advances in handling of information and telecommunications, and the emergence of increasingly sophisticated financial engineering. These factors have increased the speed and complexity of capital account 
transactions. Meanwhile, economic policy and structural changes from the standpoint of developing economies can be categorized into two broad groups: those that are country-specific, or "pull" factors; and those that are external to the country and beyond its control, or "push" factors.

One set of "pull" factors were policies that improved the relations of heavily indebted countries with external creditors. A key element was the role of debt-equity swaps in increasing the expected rate of return on domestic investment projects, thereby encouraging foreign direct investment (FDI) (Calvo, Leiderman, and Reinhart 1994). Successful price stabilization programs that were accompanied by improved fiscal policy fundamentals and greater macroeconomic stability were also major pull factors. Lastly, institutional reforms, such as the liberalization of the capital account, played a significant role in attracting capital flows. Indeed, the right to repatriate dividends and capital may have been the most important factor in the surge of foreign equity flows to emerging market economies (Taylor and Sarno 1997).

Grenville (2012) has a more intricate view of pull factors: "As emerging countries converge toward the technological frontier their capital stock is being built up from modest per capita starting levels, to eventually match the levels of the developed economies at some time in the future. During this transition, productivity will greatly increase and returns to capital will be high: the Wicksellian 'natural' interest rate in the emerging countries will be substantially higher than in the developed economies. This might be expected to be the principal underlying driver of capital flows."

Among the prominent "push" factors were the decline in international interest rates and economic recessions in industrialized countries. These factors reduced profit opportunities in world financial centers and drove international capital to emerging market economies. Another type of push factor was through contagion effects. Large shifts in capital flows to one or two large countries in a region may have generated externalities for the smaller neighboring countries (Calvo, Leiderman, and Reinhart 1996).

In terms of actual policy adjustments, regulatory changes in the US and Europe made it easier for foreign firms to make their equity and bonds more attractive to investors. This facilitated the trend toward international portfolio diversification. Meanwhile, competition and rising labor costs in industrialized countries, along with falling transport and communication costs, induced firms to seek opportunities to increase efficiency and returns by producing abroad. The realignment of major currencies contributed to this process. The result has been a progressive globalization of production and the growth of FDI flows.

A crucial debate has been on the relative importance of "pull" and "push" factors in the evolution of capital flows. If "pull" factors were the primary determinants of capital flows into emerging market economies, this would support the optimistic view that the sustainability of these flows is to a large extent a function of domestic policies under the control of developing countries. On the other hand, if the surge in capital flows was mostly a result of "push" factors, particularly interest rate movements, this would support the view that capital flows are highly volatile because they are subject to factors beyond the control of policy makers (Fernandez-Arias 1996).

The empirical evidence has generally been mixed. Some analysts argue that the weight of the evidence favors the push view - that falling US interest rates have played a dominant role in driving capital flows to developing countries (Fernandez-Arias and Montiel 1996). Other studies have shown that country-specific factors - e.g., the domestic credit rating and black market exchange premiumhave been as important in influencing capital flows, particularly portfolio flows (Taylor and Sarno 
1997). The primacy of "pull" factors, however, can be questioned on several counts. Although it is true that not all countries have been recipients of the new inflows, it is also true that flows have not been restricted to countries with well-established track records of macroeconomic and structural adjustment. Second, country creditworthiness depends not only on domestic factors but also on the international interest rate. Third, the significant role of contagion in the AFC points to the relative strength of "push" factors. The variability of capital flows, particularly to the ASEAN-5 countries (includes Indonesia, Malaysia, the Philippines, Singapore, and Thailand), was evident during the GFC (Grenville 2012).

Knowledge of the determinants of capital flows has profound implications in terms of appropriate policy responses. In this context, the overriding objective of economic managers is to maximize the benefits of capital flows and minimize their costs.

\section{B. Advantages of Greater Capital Mobility}

Greater capital mobility is generally viewed to be advantageous to the process of economic development. Capital flows to emerging market economies have eased the domestic savings constraint, which in turn has increased investment, thereby boosting economic growth. To the extent that real returns to marginal investment are lower in capital-rich countries than those in capital-scarce countries, the movement of capital from developed economies to emerging market economies improves the efficiency of world resource allocation (Devlin, Ffrench-Davis, and Griffith-Jones 1995).

Instead of raising the investment rate indirectly by providing more resources, capital flows may do so directly in the form of FDI. This type of inflow usually brings a range of dynamic benefits such as technology, improved management practices, and greater access to international markets.

The availability of international capital also provides an economy the ability to smooth expenditures, especially in the advent of adverse exogenous shocks. Meanwhile, an open capital account for both developed and emerging market economies allows for greater portfolio diversification and better management of risk on the part of investors. This is one of the more common arguments at the microeconomic level for capital account liberalization (Devlin, Ffrench-Davis and Griffith-Jones, 1995).

\section{Drawbacks of Greater Capital Mobility}

The AFC and the GFC were painful reminders of the risks associated with more open capital accounts. Foreign capital flows may cause imbalances that threaten macroeconomic stability. This situation becomes likely if the absorptive capacity of the economy falls below the level of the capital inflows. Such a disparity arises because of policy arbitrage, where capital flows are attracted by the sound fundamentals of an economy causing financial markets to allocate too much or too little capital to some recipients at a given moment (Guitian 1998).

If an economy has a flexible exchange rate regime, capital inflows will lead to an appreciation of the nominal and real exchange rates. This will have an adverse impact on the competitiveness of exports and import-substituting industries, and result in a deterioration of the current account balance. The resource allocation effects of a real exchange rate appreciation may also spawn asset price bubbles and rapid credit expansion that could jeopardize the stability of the financial system. 
In a fixed exchange rate regime, capital inflows lead to a real exchange rate appreciation via inflationary pressure brought about by the increase in money supply and domestic credit. However, a fixed exchange rate regime is more vulnerable when there is a net capital outflow. Unless it has adequate foreign exchange reserves, the monetary authority would have to raise interest rates to protect the peg. The likely outcome would be an economic recession.

Many factors could also undermine the efficacy of the capital inflows. The host economy may experience a mere substitution of domestic savings by foreign savings, which would only facilitate a consumption boom. In order to avoid this situation, a relatively high saving rate must be attained in order to generate a trade surplus that will be used to service the foreign debt incurred. But even if this saving rate is attained, an insufficient amount of investment may be channeled to the tradable goods sector (most likely because of the appreciation of the real exchange rate), which would reduce the convertibility of the surplus to foreign currency needed to service the foreign debt. Some analysts have argued that even if capital inflows are channeled completely to investment, the resulting improvement in the growth rate is only short-term in nature unless it is accompanied by a significant improvement in the economy's technology (Reisen 1998).

Since capital account inflows inherently entail financial transactions, they are also susceptible to market imperfections associated with asymmetric information and moral hazard. These microeconomic distortions normally result in an inappropriate assessment of risk exposure and cause overborrowing, making the financial system vulnerable to exogenous shocks. The problem becomes particularly acute when banks are the main intermediaries of capital flows. The situation is even more precarious in emerging markets where the risk management practices of the private sector are underdeveloped, the capacity of regulators to supervise the finance sector are limited, and the financial markets are thin.

Another potential microeconomic distortion arises from the real sector where aspects such as imperfect competition, externalities or wage rigidity, may result in inappropriate private sector adjustment even if the finance sector is functioning well (Fernandez-Arias and Montiel 1996). Such static distortions may lead to the choice of a wrong technology and access to foreign capital will magnify the problem (Calvo, Leiderman, and Reinhart 1994). Meanwhile, in the event of a sudden capital outflow, these distortions would induce exchange rate overshooting, making the economic adjustment more difficult.

This discussion is based on literature in the 1990s. The review of Kawai and Takagi (2010) presents more or less the same issues. They list three types of risks that can be conceptually considered (Kawai and Takagi 2010, 51):

Macroeconomic risks. Capital inflows could accelerate the growth of credit (or even create loss of monetary control), cause the real exchange rate to appreciate, cause inflation, and affect other macroeconomic variables in a way inconsistent or incompatible with immediate domestic policy objectives, such as price stability, exchange rate stability, and export promotion.

Financial stability risk. Capital inflows could push up equity and other asset prices, reduce the quality of assets, and adversely affect the maturity and currency composition of the balance sheets of the private sector (particularly banks and corporations), thereby contributing to greater financial fragility. 
Risk of capital flow reversal. Capital inflows could reverse themselves suddenly, with a potential for the depletion of reserves or sharp currency depreciation.

\section{Some Empirical Evidence}

Despite the theoretical and intuitive arguments in favor of greater capital mobility, some studies have questioned the benefits of capital flows on empirical grounds. In one study, an indicator of capital account liberalization was included as an explanatory variable for economic growth (Rodrik 1998). The conclusion reached was that the data provided no evidence that countries without capital controls have grown faster, invested more, or experienced lower inflation.

Another study used capital flows directly as an explanatory variable (Levine and Carkovic 1999). The authors applied more sophisticated econometric techniques to account for simultaneity, country-specific effects and the inclusion of lagged dependent variables as regressors. The study found that the exogenous components of FDI flows and portfolio flows did not exert a positive influence on economic growth. The conclusion is consistent with microeconomic studies that generally suggest that FDI does not boost economic growth primarily because of the absence of evidence of positive spillovers running from foreign-owned to domestic-owned firms. However, Reisen and Soto (2001) examined a panel data of 44 countries over 1986-1997 and found that FDI (as well as equity) inflows, but not any other type of capital inflows, are positively correlated with subsequent economic growth.

The study of Levine and Carkovic also looked at the effect of capital flows on productivity growth, which is an important determinant of the variation in long-term growth across economies. This analysis, too, did not show evidence of a link. However, a separate study by Levine (1999) presented evidence that the entry of foreign banks - a form of direct investment-enhanced the efficiency of the domestic financial system. Meanwhile, international portfolio equity flows were shown to have enhanced domestic stock market liquidity. Other studies have confirmed the positive effects of both financial system efficiency and stock market liquidity on productivity and economic growth. Hence, the study of Levine provided evidence of a transmission mechanism between foreign capital flows, on the one hand, and economic growth, on the other.

A comprehensive review by Obstfeld (2007) covers the major empirical studies of the past decade. He finds that at the macro level, in particular, it is difficult to find unambiguous evidence that financial opening yields a net improvement in economic performance for emerging countries. This does not imply, however, that financial liberalization, or specifically capital account liberalization, must be abandoned. There are plausible explanations why empirical work does not unambiguously show that capital account liberalization is beneficial on a net basis.

(i) First, there may be threshold levels of institutional development only above which the benefits exceed the costs. This could also explain why the correlation between growth and the use of foreign capital is strongly positive for industrial countries but not for lowincome countries. Other studies support this notion of a threshold effect, whereby a country's absorptive capacity must exceed a certain amount in order to exploit the benefits of capital inflows (Prasad et al. 2003).

(ii) Second, collateral benefits of openness to foreign capital are greater at higher levels of development, while the associated costs and risks are greater at lower levels of development. 
(iii) Third, crude quantity-based measures of the use of foreign finance, such as the current account deficit or gross inflows, may not capture the influence of foreign capital.

Hence, Obstfeld argues that despite the skimpy direct evidence that developing countries gain from financial globalization, they should nonetheless proceed in a cautious incremental manner. There is strong evidence that domestic financial development spurs growth under the right conditions, and these conditions-plus domestic financial development itself-are likely to make capital inflows from abroad more productive. Moreover, in the long-term, an internationally open financial system is likely to be more competitive, transparent, and efficient than a closed one.

An analysis of the macroeconomic impact of capital flows can determine whether the aforementioned drawbacks have materialized. In one study, key economic variables for selected Asian and Latin American economies were monitored using data from 1988-1994 (Calvo, Leiderman, and Reinhart 1996). Some stylized facts were documented from these observations. First, a substantial portion of the surge in capital inflows was channeled to accumulation of foreign exchange reserves. Second, in most countries, the capital inflows were associated with widening current account deficits. Third, there was a rise in consumption spending, which was usually driven by rising imports of durable goods. Fourth, in almost all countries examined, there was rapid growth in the money supply both in nominal and real terms. Fifth, the surge in portfolio flows was accompanied by sharp increases in stock and real estate prices. Lastly, the evidence on the real exchange rate presents a mixed picture. The data indicate that real exchange rate appreciation was more prevalent in Latin America than in Asia.

The stylized facts suggest that the disadvantages associated with capital flows, such as increased consumption and real exchange rate appreciation, are likely outcomes. Given the potential benefits of capital flows, it is thus imperative for policy makers to adopt measures that minimize their costs. Strategies for capital flow management can be developed at the domestic, regional, and international levels. Policy options that exist in the domestic front can further be classified into macroeconomic and microeconomic responses.

\section{E. Policy Issues}

The impact of capital flows on the exchange rate is at the heart of the discussion of appropriate policy responses in emerging markets. If capital flows are driven largely by fundamentals-such as a higher Wicksellian 'natural' interest rate or the Balassa-Samuelson effect-authorities must accept the inevitability of allowing the real exchange rate to appreciate. In fact, real exchange appreciation is the only sustainable response to a permanent increase in capital inflows and a fundamental revaluation of domestic relative to foreign assets (Kawai and Takagi 2010). Policy makers, however, are generally reluctant to allow currencies to appreciate.

Three broad categories of macroeconomic measures are available to countries facing surges of capital inflows, if they are not willing to allow the nominal exchange rate to appreciate: (i) sterilized intervention, (ii) greater exchange rate flexibility, and (iii) fiscal tightening (preferably through expenditure cuts). The relevant issues for each option are summarized in Table 1. More details can be found in Kawai and Takagi (2010).

Fiscal tightening is arguably the most effective response to a surge in capital inflows because it leads to a decline in the absorption of real resources by the public sector to offset the impact of resource transfers from abroad on the domestic economy. Because the impact is on the real sector of the economy, fiscal tightening should limit inflationary pressure and prevent a real appreciation of the 
currency. Moreover, since it can reduce pressure on interest rates, it directly lowers the gains to interest rate-induced capital inflows. Provided that government consumption is more intensive in the use of nontradable goods, fiscal tightening would cause domestic demand to shift from nontradable goods to tradable goods, and domestic production to shift from nontradable goods to tradable goods.

However, fiscal tightening has limitations as a policy tool to deal with capital inflows:

"First, fiscal policy lacks flexibility because it often requires parliamentary action. Second, there is a limit to how much fiscal policy can be tightened, especially in a democratic society and if there is little fiscal space to begin with. Third, fiscal tightening may have the perverse effect of attracting capital flows by providing a signal that authorities are pursuing a sound, disciplined macroeconomic policy. It should be countered, however, that such a positive signaling effect is likely transitory; over time, sustainable fiscal policy should help attract only the most stable and committed types of capital."

Because the policy responses presented in Table 1 have their respective drawbacks, the issue of capital controls has remained relevant. Moreover, the experience with the AFC and other similar crises has shifted the policy debate. Whereas, free flows previously dominated the analytical and intellectual debate, the current thinking has moved toward policy intervention. It has been observed that past aversion to capital controls has seemingly been replaced with a new appreciation of its contribution to economic policy as a tool for financial stability. ${ }^{2}$

However, the current positions "seem to be transitional rather than conceptually well founded" (Grenville 2012). The best example of this is the position of the International Monetary Fund (IMF) which is illustrated in Figure 1. There is acceptance that temporary management of capital flows may be necessary but only after all other possible measures have been exhausted. However, this new framework has been described as complicated, intentionally vague, and difficult to implement given the absence of explicit guidelines (Gochoco-Bautista and Rhee 2013).

1 Schadler (2010) as cited by Kawai and Takagi (2010), 61.

2 Gochoco-Bautista and Rhee (2013), 1, citing Gallagher, Griffith-Jones, and Ocampo, eds. (2012), and Jeanne (2012). 
Table 1: Summary of Policy Measures

\begin{tabular}{|c|c|c|c|c|c|}
\hline & Policy Tools & Intended Outcome & Possible Limitations & $\begin{array}{l}\text { Evidence on } \\
\text { Effectiveness }\end{array}$ & Recommended Policy Responses \\
\hline \multirow{3}{*}{ 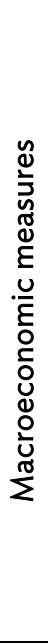 } & $\begin{array}{l}\text { Sterilized } \\
\text { intervention }\end{array}$ & $\begin{array}{l}\text { Prevent nominal and real appreciation } \\
\text { while neutralizing the growth of base } \\
\text { money }\end{array}$ & $\begin{array}{l}\text { Rising quasi-fiscal cost; higher } \\
\text { interest rates that attract additional } \\
\text { inflows; unable to prevent real } \\
\text { appreciation over the medium- } \\
\text { term due to eventual inflation }\end{array}$ & $\begin{array}{l}\text { Some evidence of } \\
\text { effectiveness in the } \\
\text { short- term, but not } \\
\text { in the medium- to } \\
\text { long-term }\end{array}$ & $\begin{array}{l}\text { Limit the use of sterilized intervention as a } \\
\text { short-run measure; reduce international } \\
\text { reserves through a reserve-sharing } \\
\text { arrangement (like a multilateralized } \\
\text { Chiang Mai Initiative) }\end{array}$ \\
\hline & $\begin{array}{l}\text { Greater exchange } \\
\text { rate flexibility }\end{array}$ & $\begin{array}{l}\text { Direct monetary policy for } \\
\text { macroeconomic management; } \\
\text { discourage speculative capital inflows by } \\
\text { creating two-way risks }\end{array}$ & $\begin{array}{l}\text { Loss of international price } \\
\text { competitiveness }\end{array}$ & $\begin{array}{l}\text { Limited evidence on } \\
\text { the response of } \\
\text { speculative flows }\end{array}$ & $\begin{array}{l}\text { Allow greater flexibility through regional } \\
\text { cooperation (see the discussion of regiona } \\
\text { collective action) }\end{array}$ \\
\hline & $\begin{array}{l}\text { Fiscal policy } \\
\text { tightening }\end{array}$ & $\begin{array}{l}\text { Contain inflationary pressure; } \\
\text { discourage capital inflows by reducing } \\
\text { interest rate pressure; prevent real } \\
\text { appreciation }\end{array}$ & $\begin{array}{l}\text { Lack of flexibility and timeliness; a } \\
\text { natural limit to the degree of } \\
\text { tightening; reduction of the } \\
\text { provision of some basic services } \\
\text { and infrastructure investment; } \\
\text { possibility of a positive signaling } \\
\text { effect to attract additional inflows }\end{array}$ & $\begin{array}{l}\text { Some evidence of } \\
\text { effectiveness in } \\
\text { preventing real } \\
\text { appreciation and } \\
\text { keeping better } \\
\text { growth performance } \\
\text { following capital flow } \\
\text { reversals }\end{array}$ & $\begin{array}{l}\text { Exploit the automatic stabilizer function of } \\
\text { the budget; that is, the government may } \\
\text { implement planned infrastructure } \\
\text { investment and basic services delivery } \\
\text { without increasing spending out of higher } \\
\text { tax revenues or reducing tax rates }\end{array}$ \\
\hline \multirow{3}{*}{ 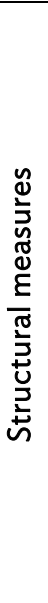 } & $\begin{array}{l}\text { Finance sector } \\
\text { reform }\end{array}$ & $\begin{array}{l}\text { Minimize the negative impact of capital } \\
\text { flow reversals by promoting risk } \\
\text { management }\end{array}$ & Not achievable in the short run & n.a. & $\begin{array}{l}\text { Strengthen finance sector supervision and } \\
\text { regulation; develop and deepen capital } \\
\text { markets }\end{array}$ \\
\hline & $\begin{array}{l}\text { Controls on capital } \\
\text { inflows }\end{array}$ & Limit capital inflows & $\begin{array}{l}\text { High administrative capacity } \\
\text { required, which is lacking in many } \\
\text { emerging market economies }\end{array}$ & $\begin{array}{l}\text { Some evidence of } \\
\text { effectiveness in } \\
\text { lengthening the } \\
\text { maturity of inflows } \\
\text { without much } \\
\text { impact on the } \\
\text { volume; } \\
\text { effectiveness tends } \\
\text { to weaken over time }\end{array}$ & $\begin{array}{l}\text { For financially open economies, carefully } \\
\text { design selective, temporary, market-based } \\
\text { controls and avoid a system of extensive } \\
\text { administrative controls. For financially } \\
\text { closed economies, pursue capital account } \\
\text { liberalization in a well-sequenced way, } \\
\text { together with institutional development }\end{array}$ \\
\hline & $\begin{array}{l}\text { Easing restrictions } \\
\text { on capital outflows }\end{array}$ & $\begin{array}{l}\text { Reduce net inflows by encouraging } \\
\text { outflows; allow residents to diversify } \\
\text { risks }\end{array}$ & $\begin{array}{l}\text { Insufficient pent-up demand for } \\
\text { foreign assets; possibility of a } \\
\text { positive signaling effect to attract } \\
\text { additional inflows }\end{array}$ & $\begin{array}{l}\text { Some evidence of } \\
\text { promoting additional } \\
\text { capital inflows }\end{array}$ & $\begin{array}{l}\text { Ease outflow controls together with } \\
\text { complementary measures such as } \\
\text { strengthening financial sector supervision }\end{array}$ \\
\hline
\end{tabular}


Table 1 continued

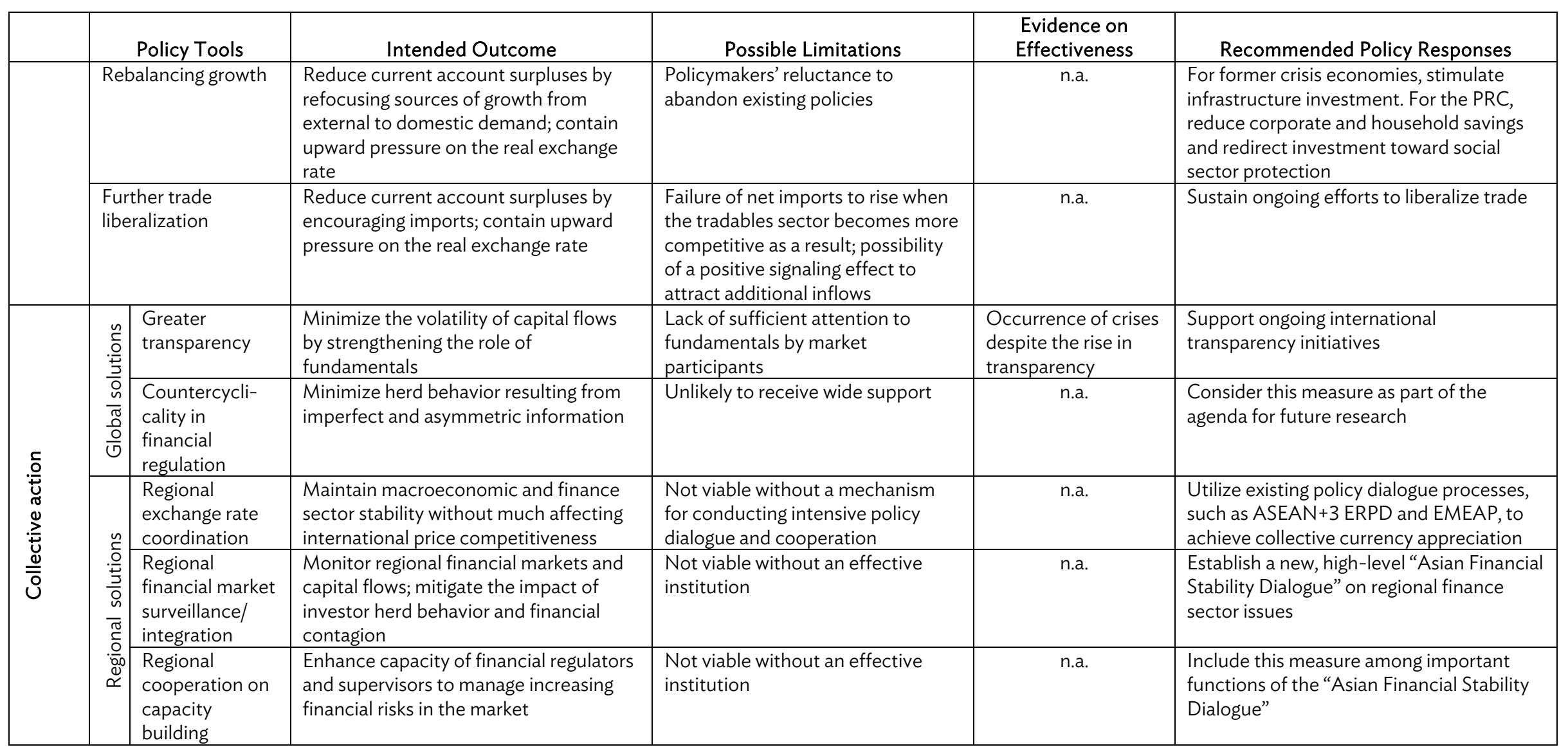

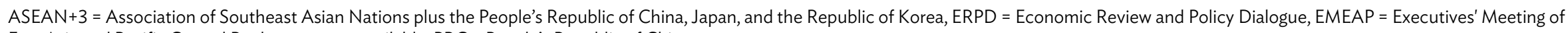
East Asia and Pacific Central Banks, n.a. = not available, PRC = People's Republic of China.

Source: Kawai and Lamberte 2010, Table 1.9, 35-38. 


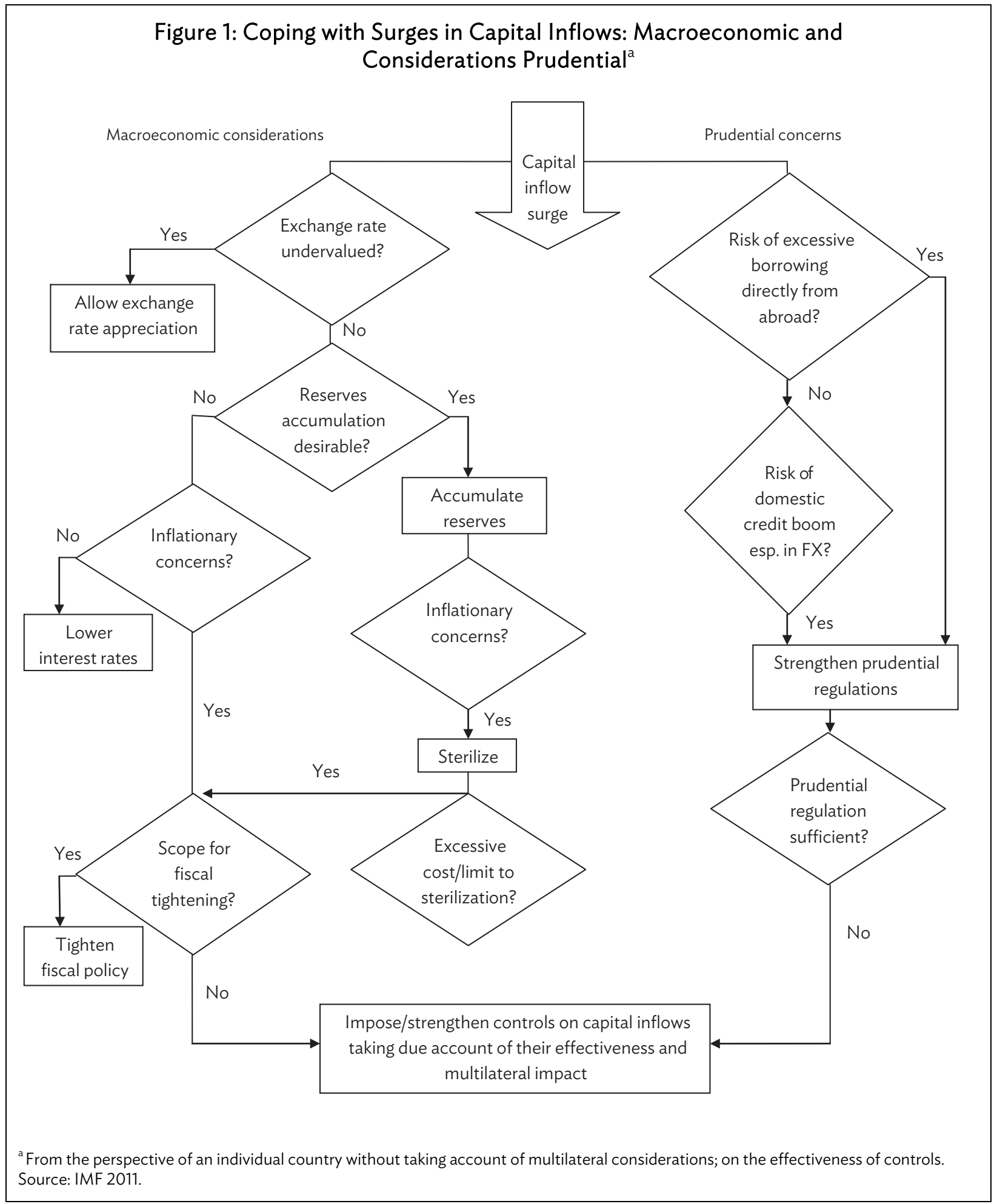




\section{CAPITAL FLOWS IN ASEAN+3}

This section presents updated data on the magnitude and composition of capital flows in ASEAN+3 as well as their impact. The presentation will largely follow the discussion of Kawai and Lamberte (2010). The data will show whether the possible drawbacks from greater capital mobility have materialized in ASEAN+3.

\section{A. Degree of Capital Account Openness}

Capital account openness has been measured empirically both in de jure (based on laws and regulations) and de facto terms. De jure openness can be more important for financial integration. One popular measure of de jure openness is the Chinn-Ito Index which is an index compiled based on the IMF's annual report on exchange rate arrangements and regulations. The index values range between 2.5 (fully open) and -1.8 (fully closed).

The degree of capital account openness varies a great deal in ASEAN+3 (Figure 2). The trend in Southeast Asia has been toward greater restrictiveness. The Philippines and Indonesia had positive values of the index prior to 2012. Malaysia's index turned negative after the AFC. Meanwhile, the index for Thailand has become progressively more negative over time. Among the economies of ASEAN+3, only the capital account of the Republic of Korea has become more open. The others either maintained the same level of openness (Hong Kong, China and Singapore) or the same level of restrictiveness (e.g., the PRC and India).

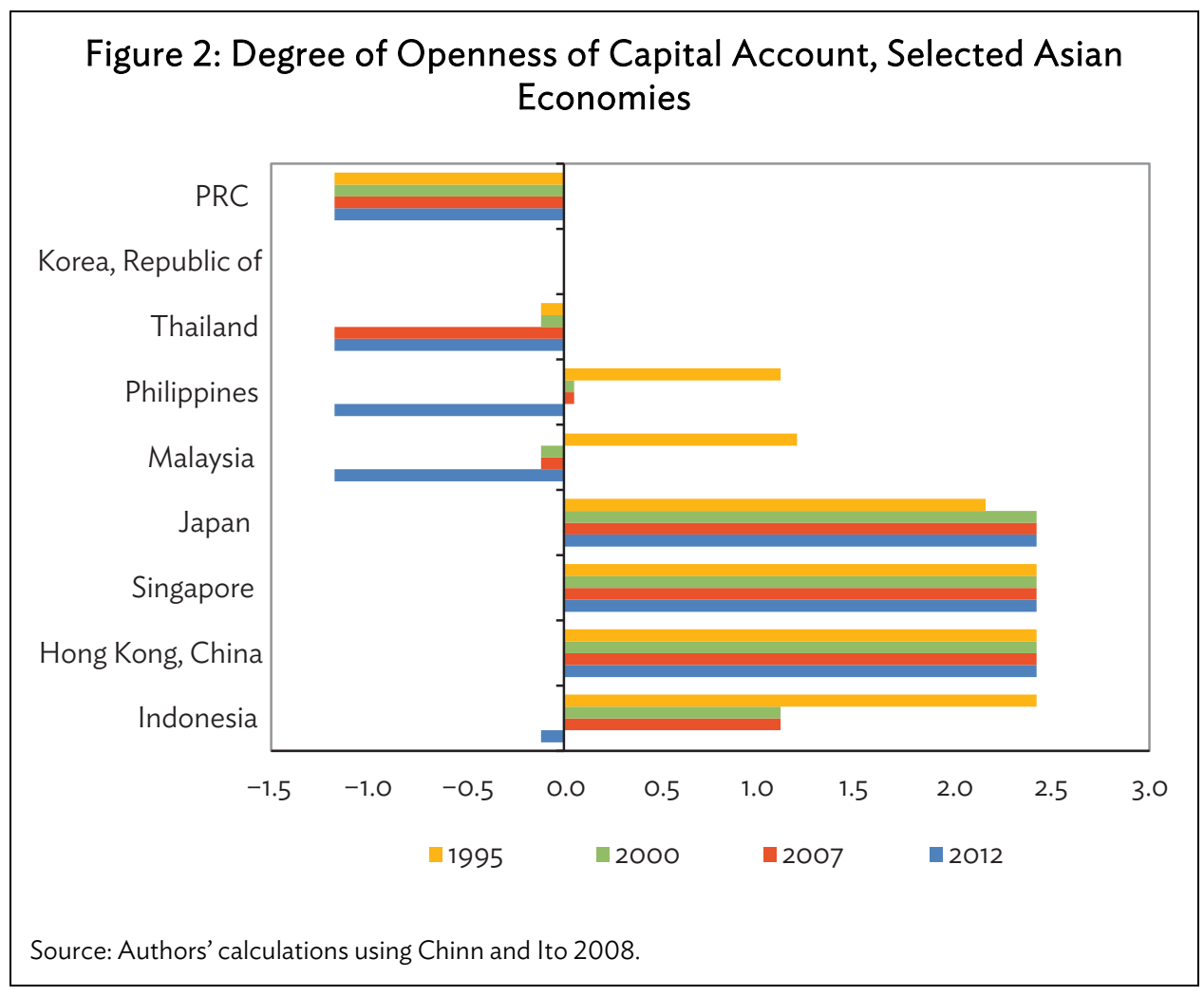


One indicator of de facto openness is the ratio of the sum of stock of assets and liabilities to gross domestic product (GDP). Using this indicator, the capital accounts of the economies of ASEAN+3 seem to be more open than indicated by the Chinn-Ito index. The ratio of total stocks of foreign assets and liabilities to GDP has been increasing over time for all the 9 economies, except Indonesia (Table 2).

Table 2: Total Stock of Assets and Liabilities, Selected Asian Economies (\% of GDP)

\begin{tabular}{lrrrrrrrr}
\hline & 1990 & 1995 & 2000 & 2005 & 2010 & 2011 & 2012 & 2013 \\
\hline PRC & 41.0 & 52.0 & 68.7 & 92.0 & 115.7 & 108.6 & 104.0 & 107.2 \\
Hong Kong, China & $1,571.9$ & $1,378.5$ & $1,256.9$ & $1,477.0$ & $2,327.9$ & $2,213.5$ & $2,364.2$ & $2,458.0$ \\
Indonesia & 83.9 & 88.5 & 131.9 & 89.2 & 85.6 & 80.2 & 83.9 & 86.2 \\
Japan & 109.1 & 83.4 & 100.9 & 154.0 & 192.5 & 195.0 & 200.5 & 246.5 \\
Korea, Republic of & 31.1 & 45.5 & 72.8 & 100.9 & 139.4 & 132.2 & 148.5 & 150.3 \\
Malaysia & 118.8 & 151.9 & 171.4 & 181.7 & 233.8 & 229.3 & 264.7 & 268.7 \\
Philippines & 93.7 & 96.5 & 124.7 & 122.2 & 108.4 & 104.5 & 119.5 & 114.0 \\
Singapore & 347.7 & 476.0 & $1,430.9$ & $1,684.1$ & $1,688.6$ & $1,527.2$ & $1,660.1$ & $1,677.0$ \\
Thailand & 68.8 & 111.6 & 137.2 & 135.9 & 176.7 & 171.2 & 195.4 & 183.4 \\
\hline
\end{tabular}

GDP = gross domestic product; PRC = People's Republic of China.

Source: Authors' calculations using the Updated and Extended "External Wealth of Nations" Dataset, 1970-2011 based on Lane and MilesiFerretti (2007) and CEIC database (accessed 8 October 2014), for 2012-2013 data following the International Investments Position reports of respective economies.

\section{B. Magnitude of Capital Flows}

Data in Table 3 show that net inflows to ASEAN+3 surged between 1993 and 1997 with a peak in 1995. This was followed by a sharp reversal in 1998 and 1999, equivalent to a combined 3.1\% of GDP. This led Radelet and Sachs (1999) to argue that the essence of the AFC was a huge, sudden reversal of capital flows, which is more prominently described as a "sudden stop." Net capital flows in the five hardest hit economies-Indonesia, the Republic of Korea, Malaysia, the Philippines, and Thailand-surged from $\$ 37.9$ billion in 1994 to $\$ 97.1$ billion in 1996. But in the last half of 1997, these flows suddenly reversed direction, with net private capital outflows totaling $\$ 11.9$ billion. Krugman (1999) succinctly states that the punishment was surely disproportionate to the crime.

Net capital flows surged again in 2003-2007. This was largely because the first 8 years of the 21 st century have been extraordinarily benign in terms of macrofinancial stability. In fact, the period was often considered a new episode in economic policy making, with the world economy entering into a "great moderation," in which better macroeconomic management made crises a thing of the past. However, there was a sudden stop again in 2008-2009 in the wake of the GFC.

The level of net capital inflows to ASEAN+3 reached new highs in 2010-2013. The situation was compounded by the massive QE by the Federal Reserve System (Fed) of the US. Between November 2008 and January 2013, the Fed engineered four QE episodes that resulted in an expansion of approximately $\$ 2.4$ trillion in base money. At the same time, the yen appreciated from $¥ 104.3$ per US dollar in September 2008 to a peak of $¥ 76.36$ per US dollar in January 2012, in line with its role as one of the three major global currencies. Other Asian currencies also experienced substantial appreciations. 
The Bank of Japan countered with a planned QE of $\$ 1.4$ trillion over a period of 2 years beginning in April 2013. The ambitious scale of the operation can be gleaned from the relative size of Japan's economy which is three times smaller than that of the US. Moreover, the time frame of 2 years is half that of the US program. In anticipation of this action from the Bank of Japan, the yen began depreciating beginning late 2012 and is currently at $¥ 106.27$ per US dollar. Most Asian currencies also depreciated during this period. The QE of Japan injected additional liquidity into the system and net capital inflows surpassed $\$ 1$ trillion, equivalent to $5.3 \%$ of the GDP of 11 ASEAN+3 economies (Table 3 ).

Table 3: Magnitude of Capital Flows, ASEAN+3

\begin{tabular}{|c|c|c|c|c|c|c|c|c|c|c|c|}
\hline Items & 1990 & 1991 & 1992 & 1993 & 1994 & 1995 & 1996 & 1997 & 1998 & 1999 & 2000 \\
\hline Capital inflows & 91.9 & 60.2 & -50.9 & 39.7 & 157.1 & 291.5 & 151.5 & 180.3 & -120.8 & -132.8 & 24.9 \\
\hline$\%$ of GDP & 2.3 & 1.3 & -1.0 & 0.7 & 2.5 & 4.1 & 2.2 & 2.8 & -2.1 & -2.1 & 0.4 \\
\hline Capital outflows & 97.4 & 91.2 & 23.8 & 99.0 & 187.0 & 265.2 & 81.8 & 304.1 & 51.3 & -86.8 & 111.0 \\
\hline$\%$ of GDP & 2.4 & 2.0 & 0.5 & 1.8 & 3.0 & 3.7 & 1.2 & 4.8 & 0.9 & -1.3 & 1.6 \\
\hline Net inflows & -5.5 & -31.0 & -74.7 & -59.4 & -29.8 & 26.2 & 69.7 & -123.8 & -172.1 & -46.0 & -86.2 \\
\hline$\%$ of GDP & -0.1 & -0.7 & -1.5 & -1.1 & -0.5 & 0.4 & 1.0 & -1.9 & -3.0 & -0.7 & -1.2 \\
\hline
\end{tabular}

Table 3 continued

\begin{tabular}{|c|c|c|c|c|c|c|c|c|c|c|c|c|c|}
\hline Items & 2001 & 2002 & 2003 & 2004 & 2005 & 2006 & 2007 & 2008 & 2009 & 2010 & 2011 & 2012 & 2013 \\
\hline Capital inflows & 3.3 & 14.3 & 171.9 & 393.7 & 301.7 & 347.2 & 724.1 & -170.1 & -238.9 & 550.1 & 586.1 & 499.3 & 889.1 \\
\hline$\%$ of GDP & 0.1 & 0.2 & 2.4 & 4.9 & 3.6 & 3.9 & 7.3 & -1.5 & -2.0 & 3.9 & 3.6 & 2.9 & 5.1 \\
\hline Capital outflows & 32.2 & 51.5 & 59.1 & 261.5 & 346.2 & 402.0 & 845.4 & 21.1 & -305.2 & 410.7 & 352.5 & 653.8 & 588.6 \\
\hline$\%$ of GDP & 0.5 & 0.8 & 0.8 & 3.3 & 4.1 & 4.5 & 8.5 & 0.2 & -2.5 & 2.9 & 2.2 & 3.8 & 3.4 \\
\hline Net inflows & -28.9 & -37.3 & 112.8 & 132.2 & -44.5 & -54.8 & -121.3 & -191.2 & 66.2 & 139.4 & 233.6 & -154.5 & 300.5 \\
\hline$\%$ of GDP & -0.4 & -0.6 & 1.6 & 1.7 & -0.5 & -0.6 & -1.2 & -1.7 & 0.5 & 1.0 & 1.4 & -0.9 & 1.7 \\
\hline
\end{tabular}

ASEAN $+3=$ Association of Southeast Asian Nations plus the People's Republic of China, Japan, and the Republic of Korea; GDP = gross domestic product. Notes: BPM6 data from 2005 onwards, BPM5 data prior to 2005. Includes the People's Republic of China, Indonesia, Japan, the Republic of Korea, the Philippines, Singapore, and Thailand.

Source: Authors' calculations using data from the IMF, International Finance Statistics; the World Bank, World Development Indicators; and CEIC database (accessed 3 October 2014); and national sources.

\section{Composition}

Figure 3 presents the composition of net inflows to 11 ASEAN+3 economies as a percentage of GDP. FDI became significant sometime in the middle of the 1990s. By the late 1990s up to the present, there were many years when FDI accounted for more than half of net inflows.

Meanwhile, portfolio equity inflows increased after the AFC. There was a sharp increase in 1999 after most Asian economies reduced barriers to investment on equity markets to recapitalize ailing banks and nonfinancial corporations (Kawai and Lamberte 2010). There was a brief lull between 2000-2002 due to the bursting of the information technology bubble and the subsequent recession in the US. Equity inflows then contributed significantly to the surge of net capital inflows during the period 2003-2007.

Debt securities inflows have been a relatively small component of net capital inflows to 11 ASEAN+3 economies. One of the causes of the AFC was the so-called double mismatcha currency mismatch and maturity mismatch-in bank balance sheets. A local bond market would be 
the natural environment to develop long-term, local currency denominated debt instruments that would provide a more stable and reliable financing framework. This will be discussed in greater detail in section V. The inflow of debt securities increased substantially in 2006-2007, particularly in the Republic of Korea and Malaysia, but the momentum was halted by the GFC.

Quite interestingly, both the AFC and the GFC are characterized by large negative flows of "other investment." 3 This type of flows or investments can readily be withdrawn by nonresidents. Apart from the smaller scale of the reversal in net inflows during the GFC, one reason why the economic impact was less compared with the AFC was the continued influx of FDI. The latter has been at a relatively stable level from 2005-2013.

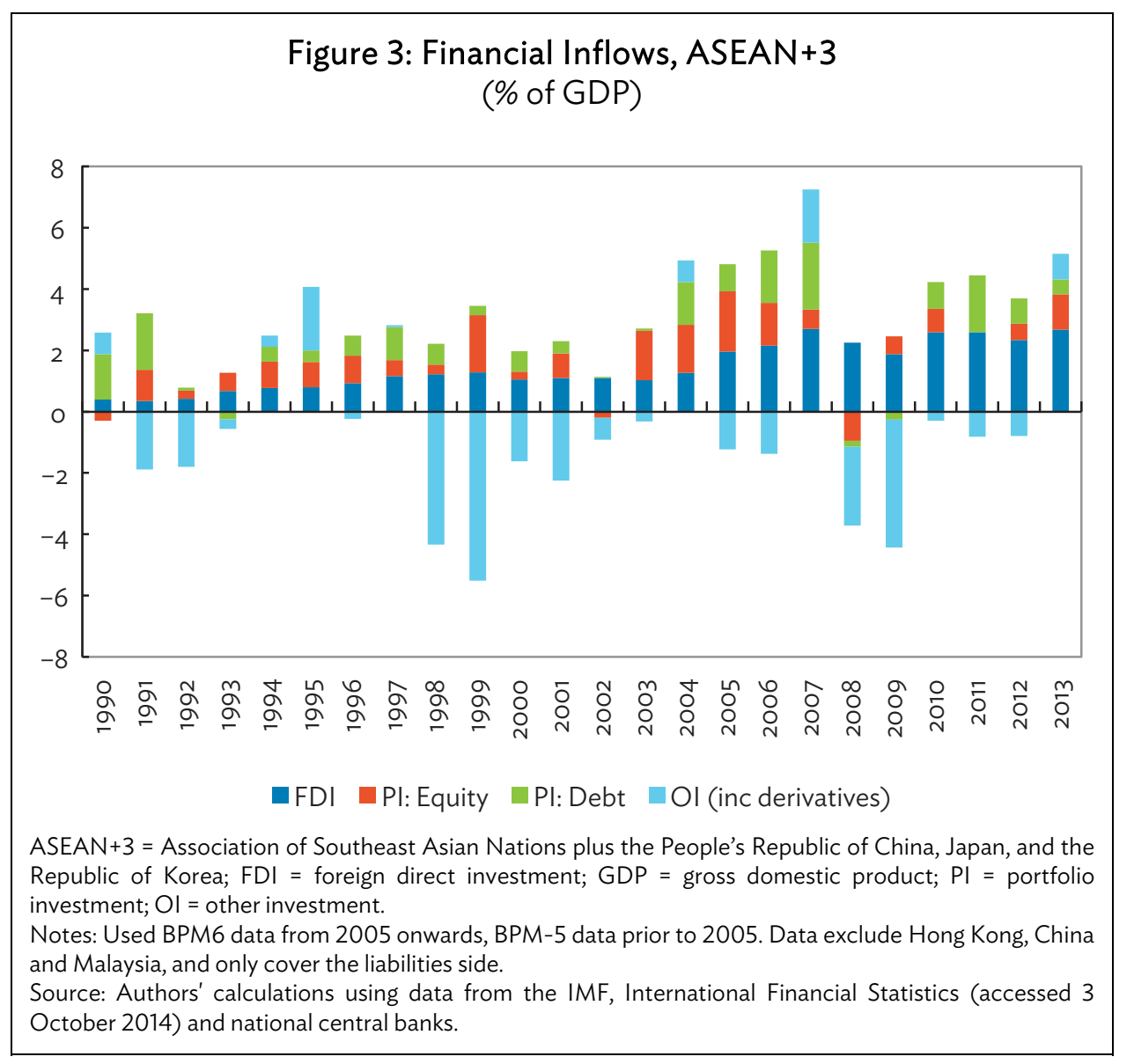

\section{Capital Flow Wave Pattern: Surge, Stop, Withdrawal, and Retrenchment}

It is useful to classify gross inflows into "surges" when there is a sharp increase in inflows, and "stops" when there is a sharp decrease in inflows (Appendix 1). For gross outflows, "flight" and "retrenchment" are used when outflows indicate a sharp increase and decrease, respectively. It is also useful to break down the flows into three types: (i) "equities" - consisting of direct investment and equity portfolio, (ii) "debt" - comprising of debt securities and others including derivatives, and (iii) "bank" flows. Flows

3 Other investment includes other equity; currency and deposits; trade credit and advances; other accounts receivable and payable; and investments other than direct investments, portfolio investments, and reserve assets. 
are considered equities-led, debt-led, and bank-led if the increase in flows is mainly through equities, debt, and bank, respectively.

Analysis of capital surge, stop, flight, and retrenchment based on one standard deviation analysis of the waves of the mean change of capital flows show that the rising volatility and persistence of capital flows in the region have not been uniform and are quite erratic (Figures 4 and 5). More so, the volatility of bank-led flows occurred most frequently. This capital flow wave pattern poses more difficult challenges to policy makers in terms of dealing with capital flow surge, stop, flight, and retrenchment, and maintain financial and macro stability.

The episodes for each type of capital flow are enumerated below.

(i) FDI inflows stand out as a very robust type of flow.

(ii) Equity flows are very volatile. In terms of period, it seems that equities have contributed to the most number of stop episodes during the dot-com bubble (Q4 2000), the GFC (Q4 2006-Q1 2007, Q1-Q3 2008), and post-GFC (Q3-Q4 2011).

(iii) Debt-led inflows have shown persistent flight during post-GFC (Q4 2009-Q2 2010).

(iv) Banking flows have contributed to several surge, stop, flight and retrenchment episodes from 1996-2013.

\section{Figure 4: Surge-Stop Episodes in Capital Inflows, Selected Asian Economies}

FDI
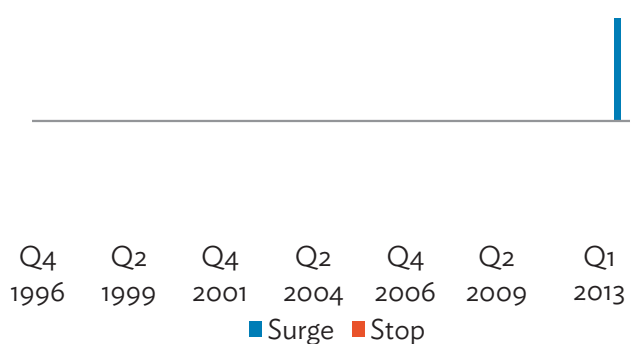

Debt

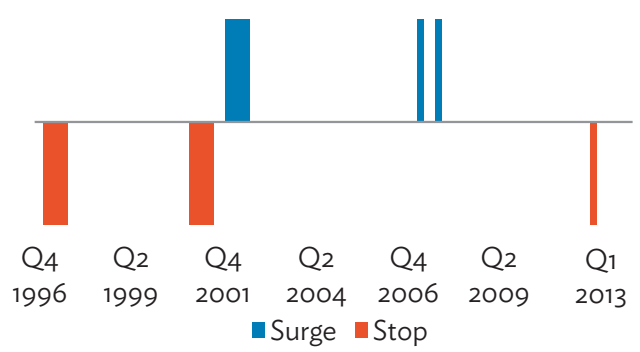

Portfolio equity securities

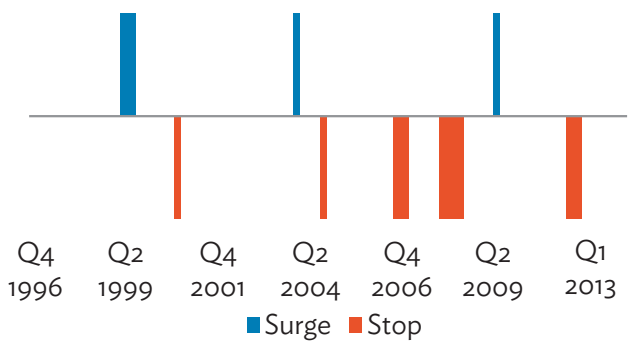

Bank transactions

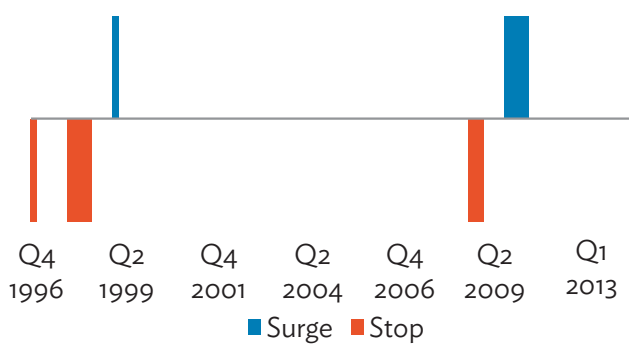

$\mathrm{FDI}=$ foreign direct investment .

Notes: Includes Indonesia, the Republic of Korea, the Philippines, and Thailand. Please see Appendix 4 for the definitions. Surge and stop markers indicate if year-on-year change of flows (based on 4-quarter moving sum) exceeds 1 standard deviation. Source: Authors' calculations using data from the IMF, International Financial Statistics (accessed 3 October 2014) and national statistics offices. 
Figure 5: Surge-Stop Episodes in Capital Outflows, Selected Asian Economies

FDI (no episodes)

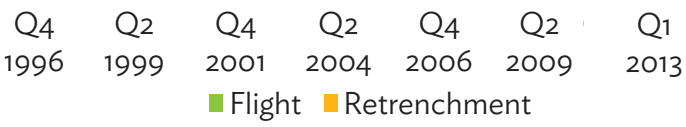

Debt

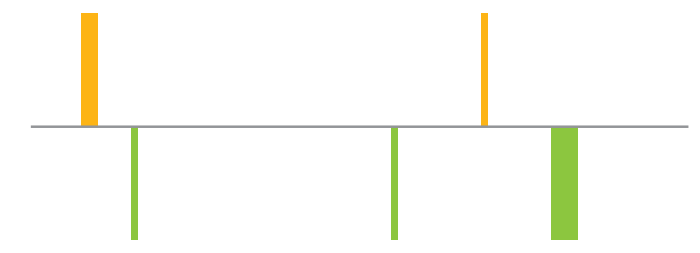

\begin{tabular}{ccccccc} 
Q4 & Q2 & Q4 & Q2 & Q4 & Q2 & Q1 \\
1996 & 1999 & 2001 & 2004 & 2006 & 2009 & 2013 \\
& \multicolumn{4}{c}{ Flight } & — Retrenchment
\end{tabular}

Portfolio equity securities

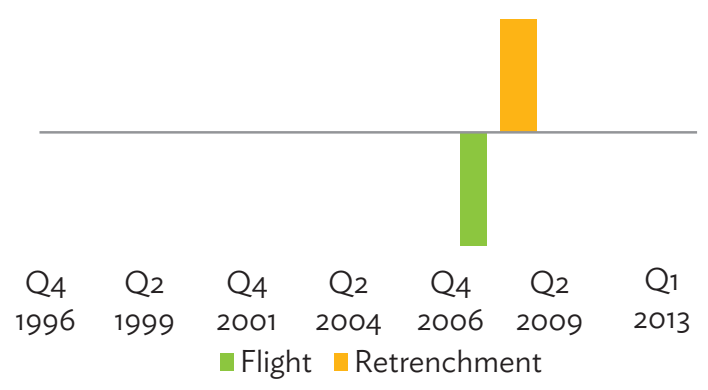

Bank transactions

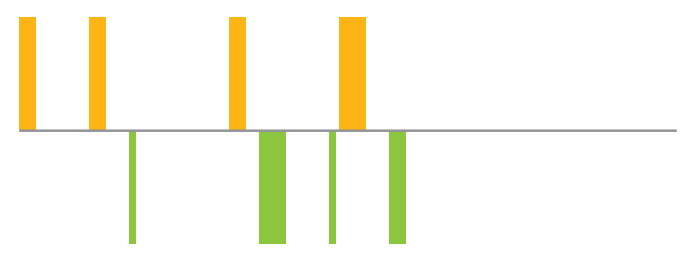

$\begin{array}{lllllll}\text { Q4 } & \text { Q2 } & \text { Q4 } & \text { Q2 } & \text { Q4 } & \text { Q2 } & \text { Q1 }\end{array}$ $\begin{array}{lllllll}1996 & 1999 & 2001 & 2004 & 2006 & 2009 & 2013\end{array}$ Flight $\square$ Retrenchment

$\mathrm{FDI}=$ foreign direct investment.

Notes: Includes Indonesia, the Republic of Korea, the Philippines, and Thailand. Please see Appendix 4 for the definitions. Flight and retrenchment markers indicate if year-on-year change of flows (based on 4-quarter moving sum) exceeds 1 standard deviation.

Source: Authors' calculations using data from the IMF, International Financial Statistics (accessed 3 October 2014) and national statistics offices.

\section{E. Impact of Capital Flows}

After the sharp depreciations during the AFC, currencies have appreciated in real terms (Figure 6a and $6 \mathrm{~b})$. The real effective exchange rate (REER) of selected economies of ASEAN+3 tended to appreciate especially after 2004, with the notable exception of Hong Kong, China and Taipei,China. The combined effect of persistent current account surpluses, rising capital inflows, and accumulation of foreign exchange reserves with persistent US deficits were the primary factors behind the appreciation of the REER (Kawai and Lamberte 2010). 
Figure 6a: Real Effective Exchange Rates, Selected Asian Economies $(2010=100)$

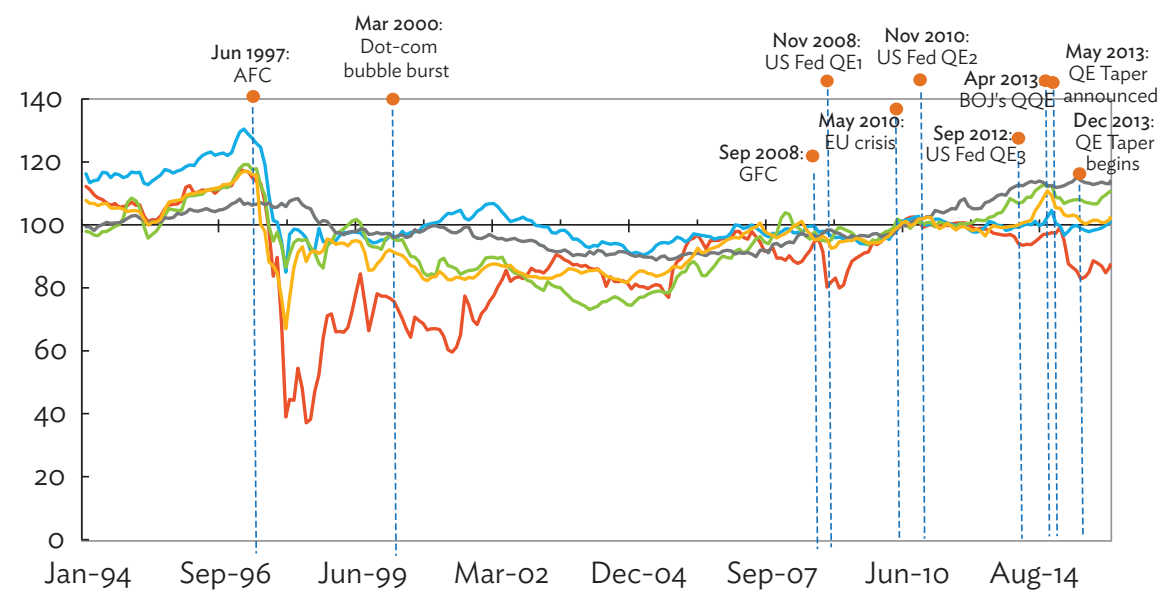

$$
\text { —Indonesia —Malaysia —Philippines —Singapore —Thailand }
$$

$\mathrm{AFC}=$ Asian financial crisis, $\mathrm{BOJ}=$ Bank of Japan, $\mathrm{EU}=$ European Union, $\mathrm{GFC}=$ global financial crisis, $\mathrm{QE}=$ quantitative easing, $\mathrm{QQE}=$ quantitative and qualitative easing, US Fed = United States Federal Reserve System.

Note: Data refer to real (CPI-based), broad indices.

Source: Bank for International Settlements.

Figure 6b: Real Effective Exchange Rates, +3 Economies and Hong Kong, China $(2010=100)$

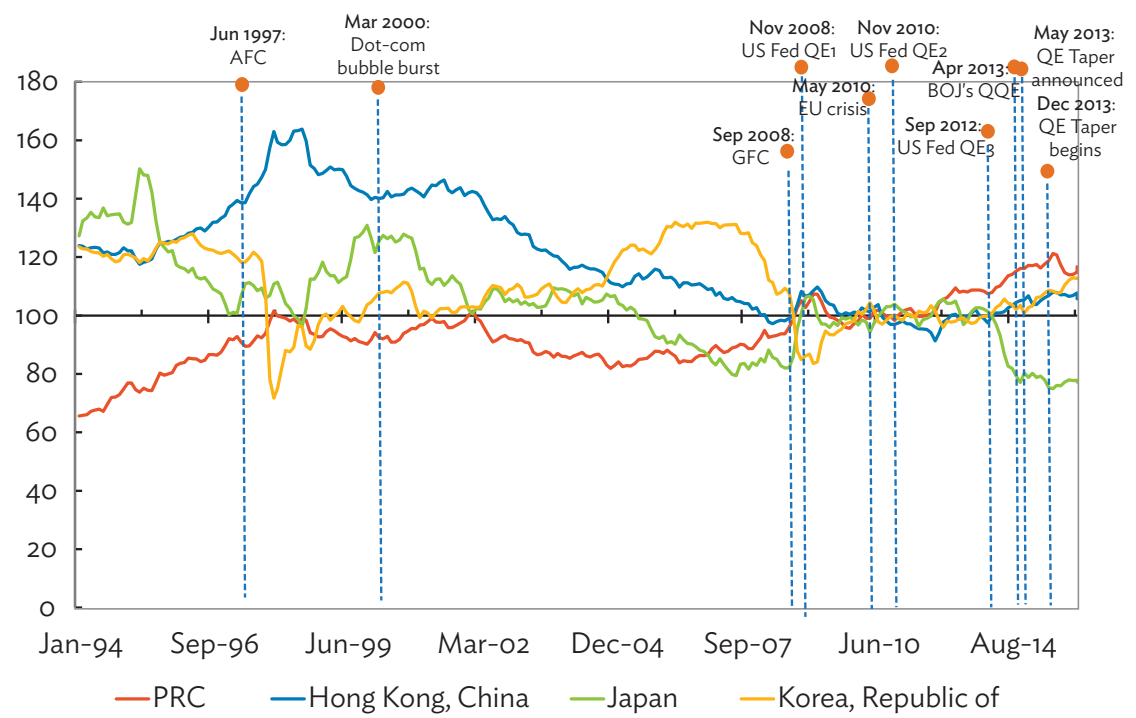

$A F C=$ Asian financial crisis, $B O J=$ Bank of Japan, EU $=$ European Union, GFC = global financial crisis, $\mathrm{PRC}=$ People's Republic of China, $\mathrm{QE}=$ quantitative easing, $\mathrm{QQE}=$ quantitative and qualitative easing, US Fed = United States Federal Reserve System.

Notes: Data refer to real (CPI-based), broad indices. Plus (+)3 includes the People's Republic of China, Japan, and the Republic of Korea.

Source: Bank for International Settlements. 
The GFC caused the trend to reverse with Indonesia and the Republic of Korea experiencing sharp depreciations in their currencies. The REER then began to appreciate for most of the economies in response to the $\mathrm{QE}$. This experience underlies the volatility of capital flows. Meanwhile, Thorbecke (2012) reports that the Japanese REER appreciated by 30\% between June 2007 and March 2009. At the same time, Japanese real exports fell $40 \%$, industrial production dropped 35\%, and the Nikkei index lost more than $80 \%$ of its value. Thorbecke (2012), as summarized in Thorbecke (2013), presents empirical evidence showing that the appreciation of the yen caused exports to fall significantly, especially for the automobile sector.

One of the more significant changes since the AFC has been the accumulation of huge foreign exchange reserves by selected economies in ASEAN+3 (Table 4). For example, the PRC's reserves exceeded $\$ 3$ trillion in 2011, equivalent to 43.7\% of its GDP. As discussed earlier, foreign reserve accumulation is one measure to stem the appreciation of an economy's currency. Some economies also heightened their reserve accumulation to protect themselves from sudden stops in capital inflows. The large holdings of international reserves could be considered excessive for some of these economies (Gagnon 2014). The Asian Development Bank (ADB) is preparing a policy note on the establishment of a new investment tool/vehicle to further support the development of the local currency bond markets in the region with the use of foreign exchange reserves. The investment tool is designed to leverage investment from global institutional investors to help broaden investor base, improve market liquidity, and reduce the risk associated with the sudden reversal of capital flows in the ASEAN+3 region.

\section{Table 4: Foreign Exchange Reserves Net of Gold, Selected Asian Economies}

\begin{tabular}{lrrrrrrrr}
\hline Level, \$ billion & 1990 & 1995 & 2000 & 2005 & 2010 & 2011 & 2012 & 2013 \\
\hline PRC & 29.6 & 75.4 & 168.3 & 821.5 & $2,866.1$ & $3,202.8$ & $3,331.1$ & $3,839.5$ \\
Hong Kong, China & 24.6 & 55.4 & 107.5 & 124.2 & 268.6 & 285.3 & 317.3 & 311.1 \\
Indonesia & 7.5 & 13.7 & 28.5 & 33.1 & 92.9 & 106.5 & 108.8 & 96.4 \\
Japan & 78.5 & 183.2 & 354.9 & 834.3 & $1,061.5$ & $1,258.2$ & $1,227.1$ & $1,237.2$ \\
Korea, Republic of & 14.8 & 32.7 & 96.1 & 210.3 & 291.5 & 304.3 & 323.2 & 341.6 \\
Malaysia & 9.8 & 23.8 & 28.3 & 69.9 & 104.9 & 131.8 & 137.8 & 133.4 \\
Philippines & 0.9 & 6.4 & 13.1 & 15.9 & 55.4 & 67.3 & 73.5 & 75.7 \\
Singapore & 27.8 & 68.8 & 80.0 & 116.0 & 225.5 & 237.5 & 259.1 & 272.9 \\
Thailand & 13.3 & 36.0 & 32.0 & 50.7 & 167.5 & 167.4 & 173.3 & 161.3 \\
\hline Proportion of GDP, \% & 1990 & 1995 & 2000 & 2005 & 2010 & 2011 & 2012 & 2013 \\
\hline PRC & 8.3 & 10.4 & 14.0 & 36.4 & 48.3 & 43.7 & 40.5 & 41.6 \\
Hong Kong, China & 31.9 & 38.3 & 62.6 & 68.4 & 117.5 & 114.8 & 120.8 & 113.5 \\
Indonesia & 6.5 & 6.8 & 17.3 & 11.6 & 13.1 & 12.6 & 12.4 & 11.1 \\
Japan & 2.5 & 3.4 & 7.5 & 18.2 & 19.3 & 21.3 & 20.7 & 25.2 \\
Korea, Republic of & 5.2 & 5.8 & 17.1 & 23.4 & 26.6 & 25.3 & 26.4 & 26.2 \\
Malaysia & 22.2 & 26.8 & 30.2 & 48.7 & 42.4 & 45.6 & 45.2 & 42.7 \\
Philippines & 2.1 & 8.6 & 16.2 & 15.5 & 27.7 & 30.0 & 29.4 & 27.8 \\
Singapore & 71.4 & 78.3 & 83.4 & 91.0 & 95.4 & 86.7 & 90.3 & 91.6 \\
Thailand & 15.6 & 21.4 & 26.1 & 28.7 & 52.5 & 48.4 & 47.4 & 41.7 \\
\hline
\end{tabular}

GDP = gross domestic product; PRC = People's Republic of China.

Source: Authors' calculations using data from the IMF, International Financial Statistics; the World Bank, World Development Indicators; and CEIC (accessed 9 October 2014). 
The growth of money supply was fairly stable for selected economies of ASEAN+3 after the AFC (Table 5). This includes the period 2010-2013 when net capital inflows to the region rose sharply. For example, money supply growth in the PRC was relatively high in 2009 (28.4\%) but this was at the time when net capital flows turned negative. Otherwise money supply growth was below $20 \%$. The stable growth of money supply suggests that the region only partially sterilized their intervention in the foreign exchange market to moderate the impact of surges in capital inflows on money supply (Kawai and Lamberte 2010).

Table 5: M2 Year-on-Year Growth, Selected Asian Economies

(\%)

\begin{tabular}{|c|c|c|c|c|c|c|c|c|c|}
\hline & \multicolumn{4}{|c|}{ Annual Average } & \multirow{2}{*}{2009} & \multirow{2}{*}{2010} & \multirow{2}{*}{2011} & \multirow{2}{*}{2012} & \multirow{2}{*}{2013} \\
\hline & 1991-94 & 1995-99 & 2000-04 & 2005-08 & & & & & \\
\hline PRC & 33.9 & 21.0 & 14.9 & 18.3 & 28.4 & 18.9 & 17.3 & 14.4 & 13.6 \\
\hline Hong Kong, China & 13.3 & 11.2 & 4.4 & 11.0 & 5.3 & 8.1 & 12.9 & 11.1 & 12.4 \\
\hline Indonesia & 19.4 & 31.0 & 10.1 & 16.4 & 13.0 & 15.4 & 16.4 & 15.0 & 12.7 \\
\hline Japan & 1.8 & 3.5 & 2.3 & 1.6 & 2.7 & 2.8 & 2.7 & 2.5 & 3.6 \\
\hline Korea, Republic of & 19.9 & 17.7 & 7.3 & 10.6 & 9.9 & 6.0 & 5.5 & 4.8 & 4.6 \\
\hline Malaysia & 17.6 & 16.3 & 9.9 & 14.1 & 9.5 & 7.2 & 14.6 & 9.8 & 8.4 \\
\hline Philippines & 21.4 & 19.2 & 8.6 & 12.5 & 8.6 & 10.9 & 5.3 & 7.0 & 29.3 \\
\hline Singapore & 11.1 & 13.5 & 3.6 & 12.8 & 11.3 & 8.6 & 10.0 & 7.2 & 4.3 \\
\hline Thailand & 16.1 & 12.4 & 6.8 & 7.4 & 6.8 & 11.0 & 15.1 & 10.4 & 7.3 \\
\hline
\end{tabular}

PRC = People's Republic of China.

Source: Authors' calculations using data from the IMF, International Financial Statistics; the World Bank, World Development Indicators (accessed 3 October 2014); and national statistics agencies.

Related to the stable growth of money supply, inflation has also been generally stable (Table 6). For the period, 2009-2013, inflation in most economies of ASEAN+3 has been relatively low. India's relatively high inflation during this period is largely due to the high cost of food owing to supply bottlenecks and the rise in rural incomes. Meanwhile, Indonesia had a bout with relatively high inflation from 2000 to 2008. Part of this was due to the reduction in fuel subsidies. Many economies also saw a surge in inflation in 2008-the reason for the increase in the average inflation for the period 20052008-because of the increases in the prices of oil, food, and other commodities in the global market. 
Table 6: Inflation, Selected Asian Economies

(\%)

\begin{tabular}{|c|c|c|c|c|c|c|c|c|c|}
\hline & \multicolumn{4}{|c|}{ Annual Average } & \multirow{2}{*}{2009} & \multirow{2}{*}{2010} & \multirow{2}{*}{2011} & \multirow{2}{*}{2012} & \multirow{2}{*}{2013} \\
\hline & $1991-94$ & 1995-99 & $2000-04$ & 2005-08 & & & & & \\
\hline PRC & 12.2 & 5.2 & 1.1 & 3.5 & -0.7 & 3.3 & 5.4 & 2.7 & 2.6 \\
\hline Hong Kong, China & 9.6 & 4.0 & -2.3 & 2.3 & 0.6 & 2.3 & 5.3 & 4.1 & 4.4 \\
\hline Indonesia & 8.8 & 20.5 & 8.0 & 9.9 & 4.8 & 5.1 & 5.4 & 4.3 & 6.4 \\
\hline Japan & 1.7 & 0.4 & -0.5 & 0.3 & -1.3 & -0.7 & -0.3 & 0.0 & 0.4 \\
\hline Korea, Republic of & 6.7 & 4.4 & 3.2 & 3.1 & 2.8 & 3.0 & 4.0 & 2.2 & 1.3 \\
\hline Malaysia & 4.1 & 3.5 & 1.5 & 3.5 & 0.6 & 1.7 & 3.2 & 1.7 & 2.1 \\
\hline Philippines & 10.6 & 7.0 & 3.8 & 5.8 & 4.2 & 3.8 & 4.6 & 3.2 & 3.0 \\
\hline Singapore & 2.8 & 1.0 & 0.8 & 2.5 & 0.6 & 2.8 & 5.3 & 4.5 & 2.4 \\
\hline Thailand & 4.6 & 5.1 & 1.7 & 4.2 & -0.8 & 3.3 & 3.8 & 3.0 & 2.2 \\
\hline
\end{tabular}

PRC $=$ People's Republic of China.

Source: Authors' calculations using data from the World Bank, World Development Indicators (accessed 3 October 2014).

Apart from the REER, the greatest impact of capital flows seems to be on equity prices (Figure 7). Between 2003 and 2007, Indonesia, India, and the PRC experienced relatively large price hikes in equity markets. Other economies also recorded increases in stock prices. The GFC disrupted the upward trend because of the global liquidity crunch and increased risks in global equity markets. The QE strategy of the US, however, brought about a resurgence in equity prices. Indonesia and India remained in the forefront. The equity market in the PRC, however, lost steam owing to concerns about future economic growth, tighter money supply, and the cooling down of the property market. Thailand and the Philippines are the two other economies with strong growth in equity prices after the GFC. Sharply rising equity prices likely indicate positive asset bubbles when market prices exceed the fundamental value. Since stocks in most of these economies are few, capital inflows lead to a surge in demand, which in turn raises equity prices to levels not supported by fundamentals. Property prices are subject to the same risk. The danger lies in an abrupt swing in the mispricing of risk: from a large underpricing of risk to a significant overpricing of risk which happened in both the AFC and the GFC. In both cases, a large negative asset price bubble spilled over to Asia (Filardo 2011). 


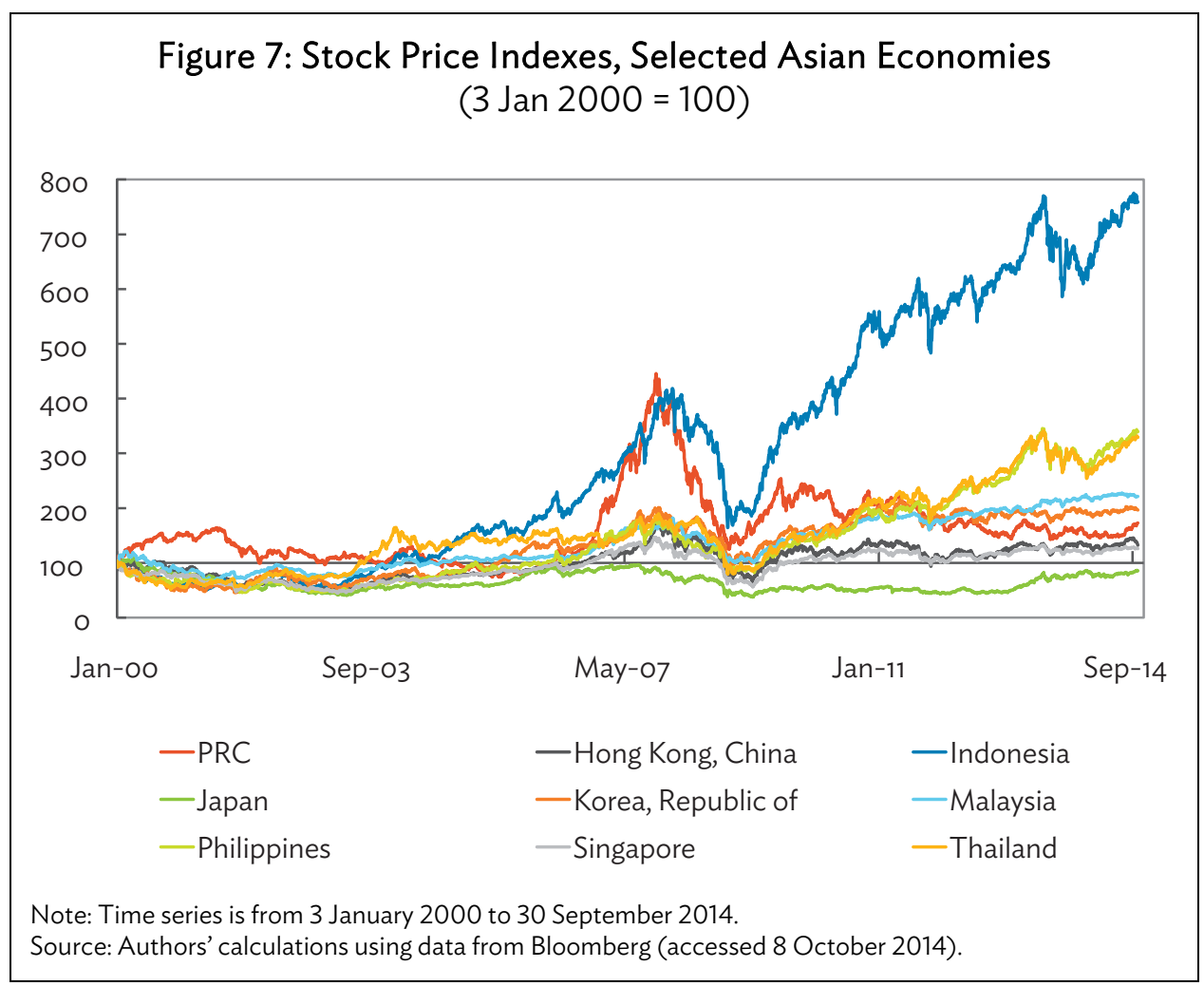

\section{CAPITAL FLOWS: RECENT TRENDS IN ASEAN+3}

Since May 2013, the tightening of interest rates in the US, what is popularly known as US QE Tapering, has ushered in a period of capital flow reversal which had significant implications for key economies in ASEAN+3. This brief discussion will characterize the nature of liquidity and capital flows to the ASEAN+3 economies. The focus is the trend of capital flows since the middle of 2012.

\section{A. Drivers of Regional Capital Flows (Quantitative Easing Tapering Period)}

The pattern of capital flow during the QE tapering period suggests strong growth of financial assets (equity, bonds, and currencies) prior to the decision to start tapering the US QE. Then, the announcement of a possible US QE tapering spawned market turmoil that saw equity markets tumble, exchange rates depreciate, and bond yields rise (Figure 8). However, these erratic market behaviors became more orderly as the US started to unwind their QE with clearer forward guidance. 


\section{Figure 8. Asian Financial Markets, Average Day-on-Day Changes on Quantitative Easing Tapering News}

\section{Equity Index (\%)}

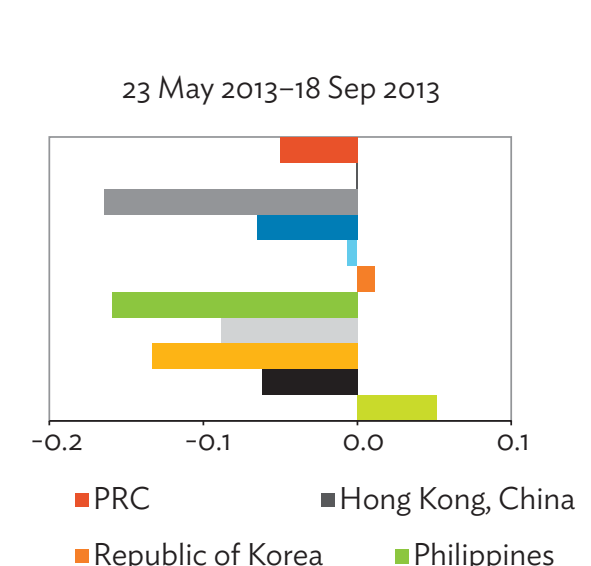

19 Sep 2013-18 Dec 2013

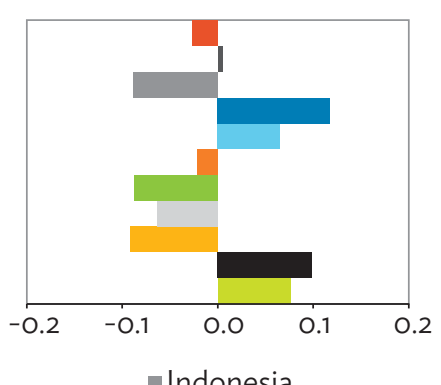

Singapore $\quad$ Thailand

Exchange Rate (\%)

23 May 2013-18 Sep 2013

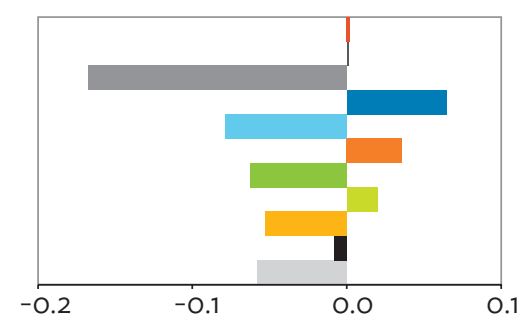

19 Sep 2013-18 Dec 2013

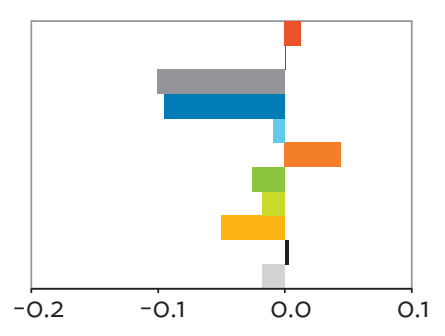

19 Dec 2013-3 Sep 2014

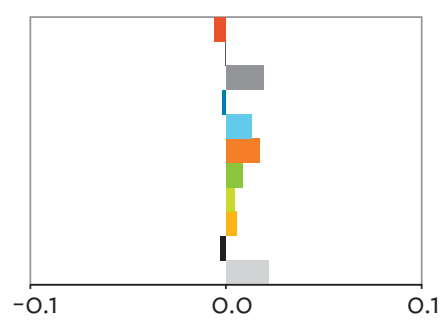

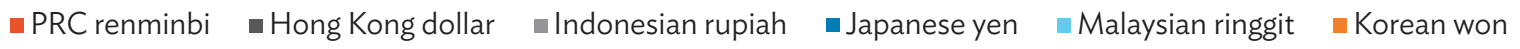

$\square$ Philippine peso $\quad$ Singapore dollar $\quad$ Thai baht $\quad \square$ Vietnamese dong

\section{0-Yr Bond Yields (bps)}

23 May 2013-18 Sep 2013

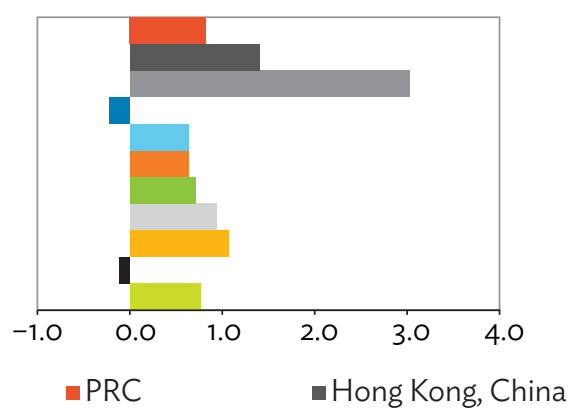

aepublic of Korea $\quad$ Philippines
19 Sep 2013-18 Dec 2013

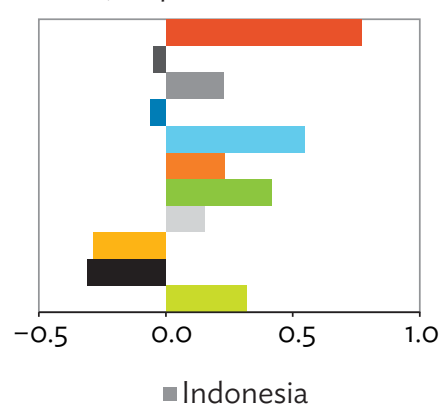

Singapore $\quad$ Thailand
19 Dec 2013-3 Sep 2014

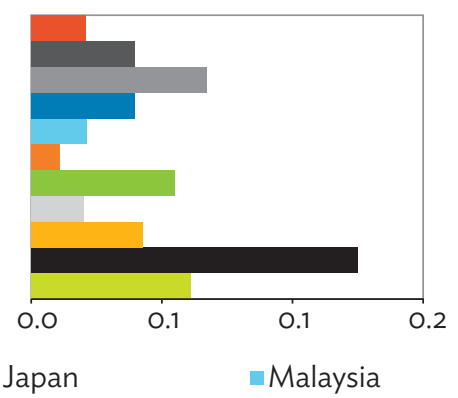

-Viet Nam United States

bps = basis points, PRC = People's Republic of China.

Notes: 22 May-US Fed first QE tapering announcement; 18 September-Postponement of US Fed QE Tapering; 18 December-US Fed begins QE tapering. Equity Indices - Shanghai Stock Exchange Composite Index used for the PRC; Hang Seng Index for Hong Kong, China; Jakarta Composite Index for Indonesia; Nikkei 225 for Japan; Kuala Lumpur Composite Index for Malaysia; Korea Stock Exchange KOSPI Index for the Republic of Korea; Philippine Stock Exchange Index for the Philippines; Strait Times Index for Singapore; Stock Exchange of Thailand Index for Thailand; Viet Nam Ho Chi Minh Stock Index for Viet Nam; and S\&P 500 for the US. Source: Authors' calculations using data from Bloomberg and CEIC (accessed 4 November 2014). 
An expectations-driven panel regression analysis was conducted to understand the effects of $\mathrm{QE}$ tapering on equities, exchange rates, and bond yields (Appendix 2). Five Asian emerging economies affected by the May 2013 QE tapering announcement were chosen. The results show the significant role played by expected increases in the US Fed interest rate, which led to (i) a decrease in foreign capital inflows to be invested in emerging market equities; (ii) a depreciation of Asian currencies; and (iii) a rise in domestic bond yields (Table 7).

Table 7: Drivers of Capital Flows, Panel Data Regression Using Five Asian Economies

\begin{tabular}{|l|cc|cc|c|}
\hline Dependent Variables & PCER & PCNEER $_{\mathrm{t}}$ & \multicolumn{2}{|c|}{ PCS\&P $_{\mathrm{t}}$} & CBondY $_{\mathrm{t}}$ \\
\hline DepVar -1 & $-0.34^{* * *}$ & $0.37^{* * *}$ & $-0.10^{*}$ & -0.07 & 0.01 \\
$\Delta$ Exp_FFF $_{\mathrm{t}}$ & $-1.58^{* * *}$ & $-0.76^{* *}$ & $-2.87^{*}$ & -1.19 & $0.38^{* * *}$ \\
Risk $_{\mathrm{t}}$ & $-6.40^{* * *}$ & $-3.95^{* * *}$ & $-25.23^{* * *}$ & $-22.71^{* * *}$ & $0.32^{* *}$ \\
$\Delta$ Exp_FFF $_{\mathrm{t}}^{*}$ taper1 & -2.06 & $-4.09^{* * *}$ & & $-16.33^{* * *}$ & \\
IPgrowth_PRC $_{\mathrm{t}-1}$ & 0.02 & 0.03 & 0.06 & $0.08^{*}$ & 0.00 \\
Indonesia & 0.06 & 0.24 & 0.52 & 0.5 & -0.05 \\
Malaysia & 0.39 & 0.24 & 0.74 & 0.72 & -0.02 \\
Philippines & 0.37 & 0.24 & 1.63 & 1.58 & -0.08 \\
Thailand & 0.34 & 0.24 & 1.44 & 1.40 & -0.25 \\
Constant & $-0.38^{* * *}$ & $-0.36^{*}$ & -1.04 & -0.98 & 0.06 \\
Adj R-Square & 0.30 & 0.27 & 0.19 & 0.21 & 0.09 \\
F-test & $* * * * * *$ & $*$ & $* * *$ & $*$ \\
\hline
\end{tabular}

${ }^{* * *}$ significant at $1 \%,{ }^{* *}$ significant at $5 \%,{ }^{*}$ significant at $10 \%$.

Notes:

1. Period from January 2010 to July 2014

2. $\mathrm{PCER}_{\mathrm{t}}$ is the percentage change in the nominal exchange rate from month $\mathrm{t}-1$ to month $\mathrm{t}$. A positive change means appreciation.

3. PCNEER $\mathrm{t}_{\mathrm{t}}$ is the percentage change in the nominal effective exchange rate from month $t-1$ to month $t$. A positive change means appreciation.

4. While the coefficient estimates for the lag of PCER and PCNEER are positive, they are less than one and could reflect persistent effects of exchange rate movements in the past; particularly since the lag is just 1 month.

5. $P C S \& P_{t}$ is the percentage change in the $S \& P 500$ Investable funds total return, which is mainly a composite price index for equities that are open to foreign investors (from month $\mathrm{t}-1$ to month $\mathrm{t}$ ) in each economy.

6. CBond $\mathrm{Y}_{\mathrm{t}}$ is the change in the country bond yield from month $\mathrm{t}-1$ to month $\mathrm{t}$.

7. DepVart-1 is the value of the dependent variable lagged one period (month).

8. $\triangle$ Exp_FFF $_{\mathrm{t}}$ is the change from month $\mathrm{t}-1$ to month $\mathrm{t}$ of 100 minus the Federal Funds Futures contract price (December 2015 maturity). 10-year Eurodollars contract (Q4 2015 maturity) used for data prior to December 2012.

9. Risk $\mathrm{t}_{\mathrm{t}}$ is the global risk measured by the change in the BBB-rated US corporate bonds spread over the US 10-year treasury rate for month $\mathrm{t}$.

10. Taper1 is dummy variable for fears for June-September 2013.

11. IPgrowth_PRC $\mathrm{t}-1$ is the year-on-year growth of industrial production of the People's Republic of China, lagged one period.

12. Indonesia, Malaysia, the Philippines, and Thailand are dummies for the countries. The default country is India.

Source: Authors' calculations.

Countering this is the impact of the global risk variable-measured by the interest rate spread between BBB-rated US corporate bonds and US 10-year treasuries-incorporating risks embodied mainly in the US economy and the EU (Figure 9). This variable significantly affected foreign capital inflows to equities as well as currencies. It has also significantly affected domestic bond yields, but less than the expected Federal funds rate. Thus, the lower the global risk perception due to global economic recovery, ceteris paribus, the more foreign inflows will go to emerging markets; Asian currencies will appreciate; and sovereign bond yields will fall. 


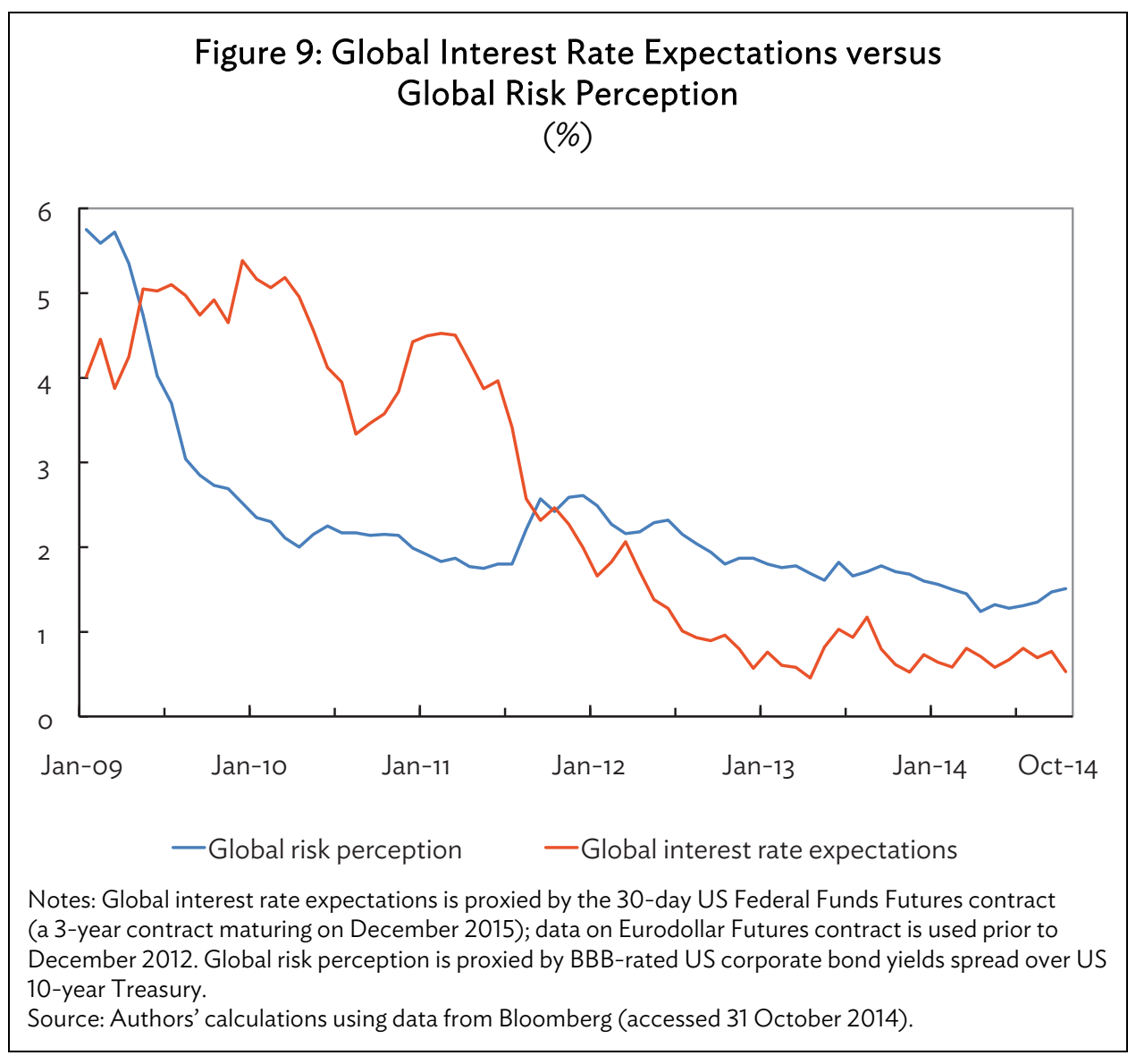

Furthermore, the regressions show that the Standard \& Poor's (S\&P) index of stocks open to foreign investors and the nominal effective exchange rate were hurt more by the tapering fears from the end of May to mid-September 2013 than the definitive announcement that tapering would begin. The mid-2013 market jitters were heightened by the uncertainty and lack of information on the size of tapering and the future US Fed interest rate policy. This was aggravated by statements of then US Fed Chairman Bernanke that tapering might start reducing new asset purchases by $\$ 20$ billion in September 2013; end the QE completely by mid-2014; and raise interest rates afterward.

In the regressions, recent financial volatility can be explained by the interplay of the expectation on the US Fed policy rate (as reflected in the US Federal Funds Futures (FFF) contract) and global risk variables. Both the FFF expectations and global risks declined from the second half of 2012 to April 2013-a period when portfolio inflows to emerging markets also became strong and, in many cases, contributed to currency appreciation. From the end of May to mid-September 2013, the FFF rose significantly from a downward trend (due to the $Q E$ ), while global risks remained stable or did not decline. Note that the FFF declined in September with the tapering postponement to approximately where it was before the jitters began. The evidence of market overreaction to US Fed tapering jitters in May to September 2013 can therefore be seen in (i) the steeper negative slope coefficient for the FFF variable revealed by the regressions on the nominal effective exchange rate and the price index of stocks open to foreign investors and (ii) the temporary spike in the FFF variable during the period. 
The model predicts that an improving global economy-especially if it is quite strong and permanent-will most likely prevent a repeat of the panic during the first tapering fear period from 23 May 2013 to 18 September 2013, as most economies will benefit with the increase in world trade and the strengthening of global financial markets. This is especially true since the risk perception variable exerts a stronger (with higher significance level) effect on the equity and exchange rate variables.

On the other hand, it appears that there was herd mentality driving capital inflows (due to the QE itself) and outflows (tapering fears). Strong capital outflows, significant currency depreciation, and increases in bond yields hit economies with strong macro fundamentals, such as Malaysia, the Philippines, and Thailand, during the tapering fears from May to September 2013 (Figure 8). Economies with weaker macroeconomic fundamentals-such as India and Indonesia-barely coped with the outflows during the same period. They suffered temporary mini crises with unusually sharp currency depreciation, alarmingly strong increases in bond yields, huge capital outflows, and reserve losses. Jacking up interest rates and imposing capital controls proved ineffective. These economies were saved when the tapering was postponed. When the tapering was announced in December, there was some brief market turbulence; but that ended a week after the late January 2014 announcement was made.

The announcement on 19 March 2014 changed the rules again as the new US Fed Chair Janet Yellen dropped the 6.5\% unemployment threshold, hinted an end to the QE by the fall of 2014, and hinted a sooner-than-expected increase in interest rates 6 months later-in the spring of 2015 instead of June 2015 as markets expected. Thus, market volatility occurred right after the announcement. But the fears seemed to have died down in succeeding days even amid the Ukraine-Russian Federation geopolitical crisis and the fear of a major slowdown in the PRC.

QE tapering is inevitable once the US and other major economies recover sufficiently. Emerging markets must readjust after the exaggerated inflows and currency appreciation that came as a result of the QE. It is clear that a strong recovery in advanced economies will be good for Asia's export-oriented economies, and Japan's continuing QE may help tame any rise in global interest rates.

However, financial markets remain highly sensitive to any news of future interest rate increases. Any hint that this would happen will again bring exaggerated fears and rumblings in the markets, with possible irrational panic and herd mentality. Thus, regional cooperation initiatives must be ready, in case market overreaction reappears as Fed tapering brings the QE to an end and leads to a rise in global interest rates. At the height of the US Fed tapering fears, cooperation in the region increased at least bilaterally. The PRC, at the peak of tapering fears in early September 2013, called on Asian economies to create more currency swap deals to facilitate capital flows. At around the same time, India and Japan decided to increase their currency swap arrangement from $\$ 15$ billion to $\$ 50$ billion. More coherent and multilateral regional cooperation and initiatives will enhance the protection of economies vulnerable to global external shocks and sharp capital outflows. Equally important, economies with weaker macroeconomic fundamentals must commit to implement clear and meaningful structural reforms, as soon as possible, to offset any market overreaction.

The market turmoil associated with last year's US Fed tapering episode flashed warning signals to economies with weak macroeconomic fundamentals-like large current account or fiscal deficits, unsustainable debt, and high inflation. India and Indonesia took the necessary initial steps toward structural reform after being hit hard by the first tapering fears. This also explains why they were less affected when tapering was actually announced in December 2013 and January 2014. 
Econometric estimation suggests that the US QE taper variable triggers capital outflow from the region, although this is partly offset by improvement in global risk conditions. Had the global risk conditions been moving in the negative territory, the region would have experienced greater capital outflow. More importantly, it seems that a market overreaction was evident.

\section{B. Analysis of Global and Regional Spillover and Contagion Effects}

Azis, Mitra, and Baluga (2013) analyzed the nature of global and regional spillover and contagion effects using bivariate Generalized AutoRegressive Conditional Heteroskedasticity (GARCH) models. Their results show that while Asian government bond returns and volatilities are influenced by dynamics of their own markets, contagion effects from the Lehman and eurozone crises were also significant in some countries (Tables 8 and 9; Appendix 3 for the methodology). In particular, the shock spillovers in 2008-2009 following the Lehman collapse affected six Asian markets-the PRC, Thailand, Malaysia, the Republic of Korea, India, and the Philippines, whereas spillovers from the eurozone crisis in 2011 affected four markets-the PRC, Thailand, the Republic of Korea, and Indonesia. The strongest shock spillovers during the eurozone crisis were in the PRC. In fact, the shock spillover coefficients throughout emerging Asia were generally higher during the 2008-2009 GFC than during the 2011 eurozone crisis, except for the PRC.

Table 8: Shock and Volatility Spillovers

(coefficients significant at 5\% level)

\begin{tabular}{|c|c|c|c|c|c|c|c|c|}
\hline \multirow[b]{3}{*}{ Source Market } & \multicolumn{4}{|c|}{ Shock Spillover } & \multicolumn{4}{|c|}{ Volatility Spillover } \\
\hline & \multicolumn{2}{|c|}{ Lehman Collapse } & \multicolumn{2}{|c|}{ Eurozone Debt Crisis } & \multicolumn{2}{|c|}{ Lehman Collapse } & \multicolumn{2}{|c|}{ Eurozone Debt Crisis } \\
\hline & $\begin{array}{c}\text { Asian } \\
\text { Market }\end{array}$ & Coefficient & $\begin{array}{c}\text { Asian } \\
\text { Market }\end{array}$ & Coefficient & $\begin{array}{c}\text { Asian } \\
\text { Market }\end{array}$ & Coefficient & $\begin{array}{c}\text { Asian } \\
\text { Market }\end{array}$ & Coefficient \\
\hline \multirow[t]{3}{*}{$\begin{array}{l}\text { US treasury bond } \\
\text { (10-year) }\end{array}$} & Malaysia & 0.1013 & & & & & & \\
\hline & Thailand & 0.0523 & & & & & & \\
\hline & PRC & 0.0149 & & & & & & \\
\hline \multirow[t]{3}{*}{$\begin{array}{l}\text { US high-yield corporate } \\
\text { bond }\end{array}$} & $\begin{array}{l}\text { Malaysia } \\
\text { Korea, } \\
\text { Republic of }\end{array}$ & $\begin{array}{l}0.4867 \\
0.3875\end{array}$ & & & PRC & 0.8546 & & \\
\hline & India & 0.2541 & & & & & & \\
\hline & Philippines & 0.2021 & & & & & & \\
\hline \multirow[t]{3}{*}{$\begin{array}{l}\text { German bunds (10- } \\
\text { year) }\end{array}$} & & & PRC & 0.0139 & & & India & 0.0007 \\
\hline & & & Thailand & 0.0092 & & & & \\
\hline & & & $\begin{array}{l}\text { Indonesia } \\
\text { Korea, } \\
\text { Republic of }\end{array}$ & $\begin{array}{l}0.0053 \\
0.0011 \\
\end{array}$ & & & & \\
\hline \multirow[t]{2}{*}{$\begin{array}{l}\text { EU composite government } \\
\text { bond (10-year) }\end{array}$} & & & PRC & 0.1619 & & & $\begin{array}{l}\text { Japan } \\
\text { Korea, } \\
\text { Republic of }\end{array}$ & $\begin{array}{l}0.8064 \\
0.0869\end{array}$ \\
\hline & & & & & & & Thailand & 0.0353 \\
\hline \multirow[t]{2}{*}{$\begin{array}{l}\text { EU high-yield corporate } \\
\text { bond }\end{array}$} & & & PRC & 0.0956 & & & Philippines & 1.9797 \\
\hline & & & Thailand & 0.0426 & & & Thailand & 0.3600 \\
\hline
\end{tabular}

EU = European Union, PRC = People's Republic of China, US = United States.

Source: Azis, Mitra, and Baluga 2013. 


\section{Table 9: Shock and Volatility Persistence (coefficients significant at 5\% level)}

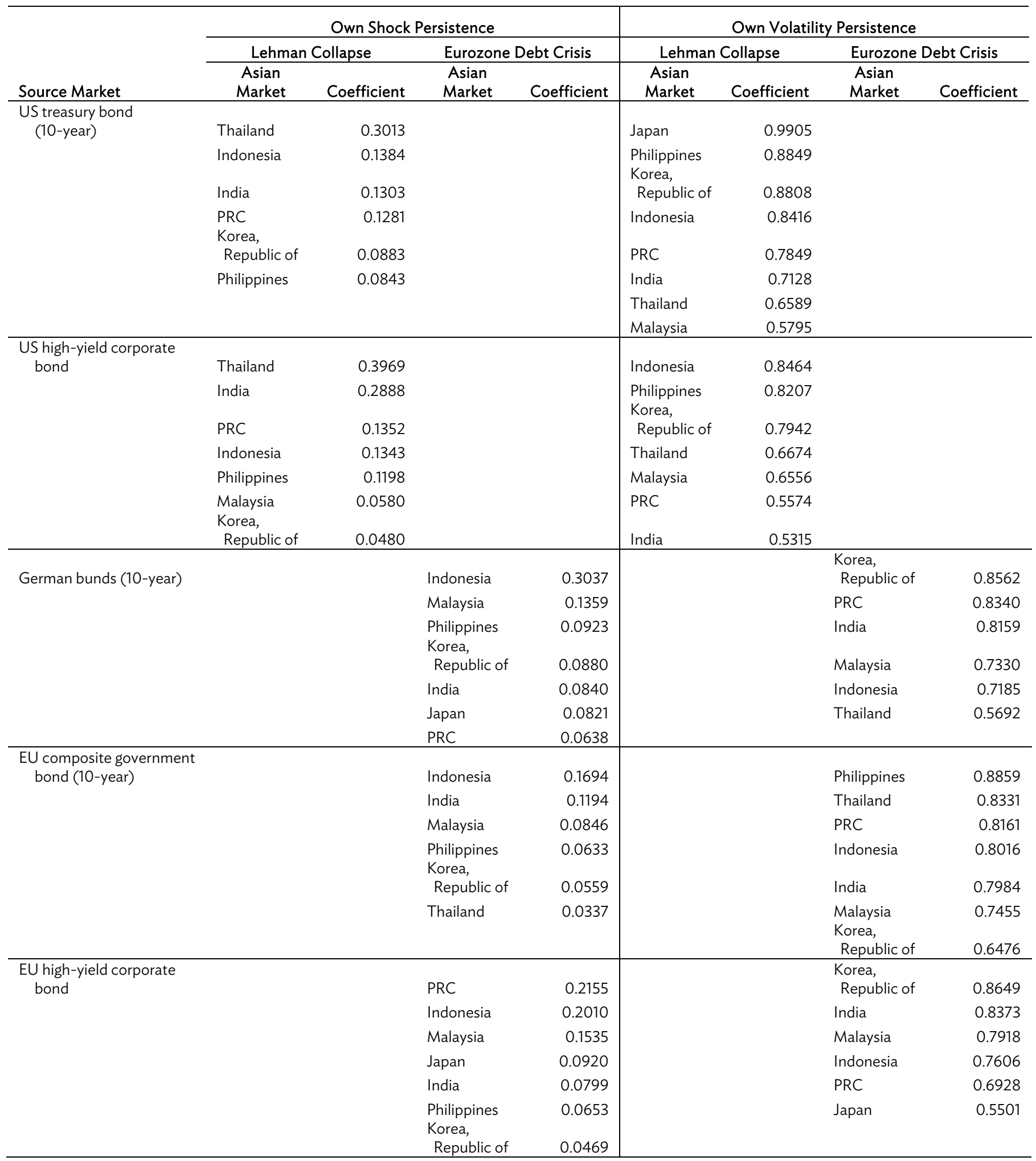

EU = European Union, PRC = People's Republic of China, US = United States.

Source: Azis, Mitra, and Baluga 2013. 
During the 2008-2009 crisis, the most significant shock spillovers came from the US highyield corporate bond market, which affected local bond markets in the Republic of Korea, Malaysia, India, and the Philippines. Similarly, there were shock spillovers from high-yielding EU corporate bond markets into local bond markets in the PRC and Thailand, and from the EU composite bond index into the PRC. In terms of volatility spillovers, perturbations in high-yield US corporate bond markets significantly affected local bond markets in the PRC in the 2008-2009 crisis; whereas during the eurozone crisis, volatile EU corporate (financial) bonds significantly affected markets in the Philippines and Thailand. These results highlight the uncertainty surrounding the transmission of spillovers from the ongoing debt crisis in the eurozone to Asia's local currency bond markets. Such transmissions imply that Asian authorities should be prepared for any possible disruptive impacts of spillovers from mature markets (Azis, Mitra, and Baluga 2013).

More recent analysis of regional spillover suggests that the role of shock spillover from Japan seems to be getting stronger, while that of the US has weakened (Table 10). ${ }^{4}$ However, this varies depending on the variable and regional group under consideration. For equity returns, intraregional spillovers or in own-country spillovers, in the case of the PRC, seem to be more dominant. For bond yield differentials, the influence of Japan is indeed stronger, but not in the PRC. Meanwhile, for exchange rate movements, the US influence has declined and this was offset by an increase in Japan's share, but only among the newly industrialized economies (includes Hong Kong, China; the Republic of Korea; and Singapore or NIE-3). Intraregional exchange rate movements were more dominant among ASEAN-4.

Table 10: Vector Autoregression Analysis: Share of Growth Variance Due to Each Economy

$(\%)$

\begin{tabular}{|c|c|c|c|c|c|}
\hline $\begin{array}{l}\text { 10-Month } \\
\text { Average }\end{array}$ & US & Japan & ASEAN-4 & NIE-3 & PRC \\
\hline \multicolumn{6}{|l|}{ Equities } \\
\hline \multicolumn{6}{|l|}{ ASEAN-4 } \\
\hline $2005-2009$ & 47.8 & 14.4 & 37.8 & - & - \\
\hline $2010-2014$ & 21.7 & 7.5 & 70.8 & - & - \\
\hline \multicolumn{6}{|l|}{ NIE-3 } \\
\hline 2005-2009 & 47.3 & 5.4 & - & 47.2 & - \\
\hline 2010-2014 & 40.9 & 4.0 & - & 55.1 & - \\
\hline \multicolumn{6}{|l|}{ PRC } \\
\hline 2005-2009 & 20.1 & 2.6 & - & - & 77.2 \\
\hline 2010-2014 & 25.5 & 2.8 & - & - & 71.8 \\
\hline
\end{tabular}

\footnotetext{
4 A Vector Autoregressive model is used for generating the variance decompositions for ASEAN-4, the NIE-3, and the PRC. Monthly data divided into two periods, January 2005 to December 2009 and January 2010 to August 2014, were used for equity returns and 5-year government bond yields data. For ASEAN-4 and the NIE-3 equity and bond indexes, market capitalization and outstanding bonds were used as weights, respectively.
} 


\begin{tabular}{|c|c|c|c|c|c|}
\hline $\begin{array}{l}\text { 10-Month } \\
\text { Average }\end{array}$ & US & Japan & ASEAN-4 & NIE-3 & PRC \\
\hline \multicolumn{6}{|l|}{ Bond Yields } \\
\hline \multicolumn{6}{|l|}{ ASEAN-4 } \\
\hline 2005-2009 & 21.4 & 1.2 & 77.5 & - & - \\
\hline 2010-2014 & 22.8 & 13.1 & 64.1 & - & - \\
\hline \multicolumn{6}{|l|}{ NIE-3 } \\
\hline 2005-2009 & 29.8 & 9.2 & - & 61.0 & - \\
\hline 2010-2014 & 25.4 & 23.2 & - & 51.5 & - \\
\hline \multicolumn{6}{|l|}{ PRC } \\
\hline 2005-2009 & 25.0 & 12.9 & - & - & 62.1 \\
\hline 2010-2014 & 4.6 & 4.2 & - & - & 91.2 \\
\hline \multicolumn{6}{|l|}{ Currencies } \\
\hline \multicolumn{6}{|l|}{ ASEAN-4 } \\
\hline \multirow{2}{*}{$\begin{array}{r}2005-2009 \\
2010-2014\end{array}$} & 17.2 & 11.6 & 71.3 & - & - \\
\hline & 3.8 & 3.1 & 93.1 & - & - \\
\hline \multicolumn{6}{|l|}{ NIE-3 } \\
\hline 2005-2009 & 7.1 & 4.3 & - & 88.6 & - \\
\hline 2010-2014 & 2.4 & 8.7 & - & 88.9 & - \\
\hline \multicolumn{6}{|l|}{ PRC } \\
\hline 2005-2009 & 13.9 & 4.9 & - & - & 81.2 \\
\hline 2010-2014 & 6.1 & 1.5 & - & - & 92.4 \\
\hline \multicolumn{6}{|c|}{$\begin{array}{l}\text { ASEAN = Association of Southeast Asian Nations, NIE = newly industrialized economy, PRC = People's Republic of } \\
\text { China, US = United States. } \\
\text { Notes: ASEAN-4 includes Indonesia, Malaysia, the Philippines, and Thailand. NIE-3 includes Hong Kong, China; the } \\
\text { Republic of Korea; and Singapore. } \\
\text { Based on estimated VAR model. Cholesky orderings are as follows: the US, Japan, followed by either ASEAN-4, the } \\
\text { NIE-3, or the PRC. Equity indices for ASEAN-4 and the NIE-3 are weighted according to market capitalization; bond } \\
\text { indices for ASEAN-4 and the NIE-3 are weighted according to total bonds outstanding; currencies for ASEAN-4 and } \\
\text { the NIE-3 are weighted according to total trade with the US. Horizontal values sum to } 100 \text {. } \\
\text { Source: Authors' calculations using data from AsianBondsOnline, Bloomberg, and World Federation of Exchanges. }\end{array}$} \\
\hline
\end{tabular}

\section{POLICY RECOMMENDATIONS}

Greater global capital flows is a reflection of increasing financial integration. Policy recommendations on how to manage capital flows are therefore designed to maximize benefits or minimize costs of greater financial integration. The main areas for consideration are policies to influence the composition of capital flows toward a greater share of FDI, macroprudential policies to support financial stability, exchange rate coordination to reduce the resistance of policy makers to currency appreciation, and regional financial cooperation to address possible externalities in capital flows.

Most of these policies are derived from country experiences and literature reviews. Those that relate to the process of regional cooperation in Asia are discussed in a separate section. Capital controls are a subset of macroprudential polices. However, they generate a lot of debate on their effectiveness. The policy recommendations based on the study of Molnar, Tateno, and Supornsinchai (2013) are also presented in a separate section. 


\section{A. Increase Foreign Direct Investment and Its Share in Capital Inflows}

Standard measures to attract more FDI relate to better physical infrastructure, higher quality of human capital, and improved governance. This topic has been analyzed and discussed extensively. This section looks into how the ASEAN Economic Community (AEC) can be structured to attract more FDI into Southeast Asia. ${ }^{5}$

The removal of regulatory and legal barriers to international capital flows and the participation of foreign investors in domestic firms and financial markets will lead to more FDI, but significant increases in FDI can be realized only if the most important sectors are opened up and member states improve their core business environment. This requires that member states implement complementary policies that help improve the investment climate.

Individual ASEAN countries are facing the huge challenge of improving their competitiveness. As many experts have noted, a large market is a powerful draw for investors, but multinational corporations serving global markets increasingly look for world-class infrastructure; skilled and productive workers; innovative capabilities; and an agglomeration of efficient suppliers, competitors, support institutions, and services. To be successful, the implementation of the AEC must be accompanied by complementary policies and programs, especially at the national level. For example, member states would do well to:

(i) continue implementing reforms under the AEC and the ASEAN Comprehensive Investment Area (ACIA) commensurate with improvements in their domestic business environment, including economic regulations, corporate governance, and labor policies;

(ii) develop logistics infrastructure and strengthen legal systems to increase FDI inflows; and

(iii) devise, unilaterally and collectively, structural adjustment and reform assistance programs as well as capacity building measures to help those who could be adversely affected by reforms.

In a comprehensive study of the impact of the ASEAN Investment Area (AIA) on FDI inflows to ASEAN, Plummer (2007) concludes that the AIA has had a generally positive effect and has helped open up sectors and reduce barriers to investment. To strengthen and enhance the AIA, the author proposes the following actions:

Introduce collective measures to be taken by all the ASEAN member states and encourage individual member states to lower transaction costs and strengthen market factors to facilitate investment and promote regional production networks.

(i) Widen the scope of industries by transferring Mode 3 services from the ASEAN Framework Agreement on Services (AFAS) to the AIA.

(ii) Combine the AIA, the 1987 Agreement for the Promotion and Protection of Investments, and appropriate provisions of bilateral investment treaties into a comprehensive "AIA-Plus" agreement. (The AIA was eventually expanded to ACIA).

5 The discussion is lifted from Aldaba, Yap, and Petri (2009), 106-108. 
(iii) Harmonize national provisions on equity ownership, land tenure, nondiscriminatory taxation, movement of skilled labor, and financial flows at the ASEAN regional level to ensure national treatment.

(iv) Consolidate timeframes for actions.

(v) Identify and then remove investment impediments, using specific procedures, and within a specific timeframe.

(vi) Reduce the number of industries and sectors under the sensitive list and review those covered, with a view toward a phaseout.

(vii) Make the AIA-Plus an integral part of the AEC, as its provisions would cover investments, services, capital flows, and skilled labor associated with investment.

(viii) Establish a mechanism for monitoring progress.

(ix) Expand the mandate of the ASEAN Secretariat and strengthen its technical and analytical capabilities.

These recommendations were made several years ago but most of them remain relevant in the build up toward the establishment of the AEC at the end of 2015.

\section{B. Macroprudential Policies}

Potential costs of capital inflows can be minimized. Macroprudential policy can act as a safeguard for financial stability, in particular to deal with the credit and asset price cycles driven by global capital flows (Zhang and Zoli 2014). The experience with both the AFC and the GFC showed that macroprudential policy should be implemented in order to prevent financial volatility from overcoming sound macroeconomic fundamentals. Zhang and Zoli (2014) find that over time, Asian economies appear to have made greater use of macroprudential tools, especially housing-related measures, than their counterparts in other regions. Their analysis suggests that macroprudential policy and capital flow measures have helped curb housing price growth, equity flows, credit growth, and bank leverage. The instruments that have been particularly effective in this regard include loan-to-value ratio caps, housing tax measures, and foreign currency-related measures. These are similar to the findings of Molnar, Tateno, and Supornsinchai (2013).

Figure 3 shows the level and composition of capital inflows into 11 ASEAN+3 economies. The composition affects the degree of volatility of capital flows and therefore, the risk of "sudden stops" (section III, and Figures 4 and 5). The higher share of FDI during the GFC episode compared with the AFC is an important factor in explaining why the ASEAN+3 economies were not as hard hit by the GFC. Moreover, it is believed that the behavior of domestic investors during periods of financial stress is more stabilizing than that of foreign investors (Jeanne 2014). To influence both the composition and level of capital flows, macroprudential policies have to be put in place. But with the advent of greater financial integration, capital controls-a form of macroprudential policy-must be endorsed at the international level in order to be effective (Grenville 2012). In the absence of such an endorsement, for example from the IMF, regional cooperation on capital controls is a second best solution. Regional cooperation on macroprudential policy can also address possible policy spillovers, (e.g., cross-border impacts of blanket guarantees of deposit insurance, capital control measures, or adoption of macroprudential policies), which could have side effects on capital flows that could be destabilizing for other economies in the region (Kawai and Morgan 2014).

Another reason that macroprudential policies have become important is because the specific cause of a crisis becomes different with each episode. Macroprudential policies can reduce systemic risk by reducing excessive capital flows. However, macroprudential policies have to be implemented 
with caution. For one thing, Azis (2014) argues that monetary policy has to take into account the macroeconomic effects emanating from macroprudential policy, and vice versa. This is related to one of the building blocks of macroprudential policy, which consists of designing a set of internally consistent macroeconomic policies involving both monetary and fiscal policies (Brunschwig et al. 2011). One argument is that reasonable prudential policies may not suffice to maintain financial stability if they are not supported by practical monetary policies. For example, raising credit standards will not effectively contain excessive leverage if very low interest rates are maintained for so long that they foment excessive risk-taking.

\section{Capital Controls}

The main issue with regard to capital controls is their effectiveness. This will depend largely on the nature of the flows, the structure of the economy, and the capacity of the economic authorities. The study of Molnar, Tateno, and Supornsinchai (2013) provides a useful empirical analysis for the Asia and Pacific region. It has two main objectives: (i) to assess the degree of countries' openness to capital flows and its variation across countries and over time and (ii) to investigate what types of factors-including different types of controls on the flow of capital-drive sudden changes in various types of inflows and outflows. The major findings are as follows (Molnar, Tateno, and Supornsinchai 2013, 32-34):

Targeted controls appear effective. Capital inflow bonanzas on the portfolio account can best be prevented by not allowing residents to sell, issue, or purchase bonds abroad or nonresidents to sell or issue equities in the domestic market. Selling or issuing bonds abroad by residents is mostly in larger quantities due to the fixed costs of issuance and the economies of scale; therefore, restricting this activity is clearly a way to avoid large and sudden inflows. A similar explanation may hold for foreign equity issues in the domestic market. To avoid debt portfolio inflow bonanzas, the key is to limit the inflow of money market and collective investment instruments. Among the inflow measures, it is the sale or issuance abroad of money market or collective investment instruments by residents that are shown to be effective to avoid debt portfolio investment booms.

The policy environment matters. Previous inflows of the respective type of capital have an independent explanatory power in determining inflow bonanzas. That is, increasing inflows may be a warning sign of a coming boom. Conversely, the stock of inflows appears to have a negative impact on the probability of an inflow bonanza in the case of equities and positive in the case of cross-border credit, though in this latter case, only for large inflows. The stock of inflows does not appear to affect the probability of portfolio investment inflow booms. Previous growth performance of the domestic economy increases the probability of equity inflow booms, but not of other types of capital. Global risk appetite also makes inflow booms more likely in the case of overall inflows, equity portfolio investment and cross-border lending. In the case of financial credit bonanzas, the depth of the financial system is an important determinant of bonanzas-deeper financial markets are less prone to experience volatile inflows. This finding has direct policy implications-the deepening of financial markets can reduce the probability of volatile flows; or, without deep financial markets, it may be hazardous to open up the capital account to cross-border flows.

Controlling resident flows appears more effective. The pattern emerged from the analyses of the determinants of the probability of inflow bonanzas suggests that control measures targeting residents may be more effective than those targeting nonresidents. In particular, restricting the sale or issuance of equities, bonds, money market instruments and collective 
investment instruments abroad by residents, appeared effective in reducing the probability of inflow surges.

In addition, limiting the purchase of bonds, money market instruments and collective investment instruments by residents also seems to effectively reduce the probability of inflow bonanzas that is more puzzling. While the sale or purchase of such instruments is an outflow from the balance of payments' point of view, the restriction of purchasing such instruments may affect the probability of sudden inflows by inhibiting the ability of domestic investors to repatriate large amounts of funds previously invested in these instruments owing to, for instance, heightening of global risk aversion or urgent repatriation needs related to the domestic economic environment or business operations. In contrast, restricting flows of foreign-owned capital appears to work only in a few cases, such as controlling collective investment instruments, in particular, their sale locally by nonresidents and the sale and issuance of bonds by nonresidents.

Another proposal on the implementation of capital controls has been provided by GochocoBautista and Rhee (2013). They suggest that the absence of persistent current account imbalances be a precondition to the use of capital controls. This is anchored on the principle that a country's sovereign right to use all available tools and implement policies that they deem best should be respected, as long as there are no substantial negative externalities on other countries.

\section{Exchange Rate Coordination Has to Be Reconsidered}

One reason for the concern over currency appreciation is that policy makers are concerned that domestic firms will lose competitiveness either in the domestic or global markets. The exchange rate also influences the current account and was a key factor in the AFC. It will be useful if the exchange rate can be part of the monitoring and surveillance process in Asia. There need not even be reference to a long-term goal of a single currency. Exchange rate coordination can be conducted at a rudimentary level. What is important is to determine if there are sizable changes in the REERs that may lead to imbalances; or else, macroeconomic imbalances can cause excessive exchange rate volatility.

This issue was examined recently by Kawai and Pontines (2014). They too find that since 2000, the PRC authorities and those of most East Asian currencies have increased their exchange rate flexibility against the US dollar. They also consider how greater regional monetary and currency coordination could help to achieve intra-East Asian exchange rate stability. Given that the renminbi operates on a standard drawing right (SDR) basket system (comprising the US dollar, euro, pound sterling, and yen) and most other East Asian currencies on an SDR+ basket system (comprising the same currencies plus an emerging East Asian currency such as the renminbi), achieving intraregional exchange rate stability may be difficult. For a start, the PRC would have to reduce the weight of the US dollar in its dollar-dominant SDR basket system and increase exchange rate flexibility substantially if significant capital account liberalization is to be achieved. The study suggests that a transition to greater convergence of exchange rate regimes would have to begin with similar managed floating regimes based on an SDR or SDR+ basket and then move to an Asian Currency Unit (ACU) basket once sufficient economic and structural convergence has been achieved among the economies.

This study does not recommend any particular approach to exchange rate coordination. What is important is to resurrect this issue and make it part of the agenda of either the Economic Review and Policy Dialogue (ERPD) or the ASEAN+3 Macroeconomic Research Office (AMRO), or both. 


\section{E. Regional Financial Cooperation}

An effective policy agenda for financial liberalization focuses on maximizing the gains and minimizing the risks associated with financial development. Such an agenda would entail adoption of policy measures at all levels: domestic, regional, and international. A major issue in this section is how regional financial cooperation can facilitate the transition to financial openness, including capital account liberalization. ADB (2008) identifies the major weaknesses in any given financial regime to be:

(i) insufficient market opening and capital account liberalization;

(ii) limited and varying degrees of transparency, financial regulation, financial supervision, and governance;

(iii) inadequacies in risk management in financial firms and markets; and

(iv) the heterogeneity of supervisory, accounting and auditing rules, and regulatory frameworks across countries.

A prioritized agenda for countries deepening their financial development would include: (i) strengthening the banking sector primarily by improving its regulation and supervision; (ii) adoption of international norms and standards; and (iii) promotion of capital markets, especially local currency bond markets, to create the liquidity and innovative financial products required to attract a broader and more diversified investor base.

Can regional financial cooperation in Asia advance the development of the financial system and if so, how? The main avenue is through the development of the local bond market, which would be the natural environment to develop long-term, local currency-denominated debt instruments that would provide a more stable and reliable financing framework. Many Asian economists and policy makers argued that an integrated Asian bond market would be valuable in achieving such a liability structure (Ito and Park 2004). Following this view, Asian authorities initiated various regional initiatives to strengthen and deepen local currency bond markets. The monetary authorities of East Asia launched the Asian Bond Markets Initiative (ABMI), which focuses on the supply side or infrastructure of bond markets, including clearing and settlement systems, rating agencies, and denomination currencies.

Meanwhile, the Executives' Meeting of East Asia and Pacific Central Banks launched the Asian Bond Fund in 2003 to promote the development of national and regional bond markets by directly creating bond funds. The Asian Bond Fund framework has made local currency bonds more attractive to investors and helped develop deeper and more liquid national bond markets. It has also encouraged regulatory and tax reforms - for instance, prompting some national governments to offer withholding tax exemptions on investment income to nonresident investors and others to loosen capital controls.

Since 2008, ASEAN+3 has focused on four key areas in developing the local currency bond markets (LCBMs) under ABMI, namely: (i) promoting issuance of local currency bonds (LCBs), (ii) facilitating the demand of LCBs, (iii) improving the regulatory framework, and (iv) improving related infrastructure for bond markets.

The establishment of the Credit Guarantee and Investment Facility (CGIF) was a measure intended to promote the issuance of LCBs. The CGIF is an important outcome of the ABMI that has been gradually developed since 2005 through policy dialogue, close coordination, and collaboration between ASEAN+3 and ADB. The finance ministers endorsed the creation of a credit guarantee and 
investment mechanism as a trust fund of $A D B$. The establishment of the CGIF trust fund was approved by ADB's Board of Directors in April 2010, with an initial capital of $\$ 700$ million. The CGIF seeks to promote the development of Asian bond markets by providing guarantees for investors that make it easier for firms to issue local currency bonds with longer maturities. Longer term, it is expected to promote the harmonization of standards and practices for bond issuance and help channel Asia's savings to finance long-term investment in local currencies, notably in regional infrastructure and other key areas. This, in turn, will promote regional financial market integration, make Asia less vulnerable to external shocks, and boost economic growth. CGIF is expected to issue several credit guarantees for bonds issued within the region in 2014. There could be a new call for capital increase as CGIF has already increased its leverage ratio from 1 to 2.5 .

To facilitate the demand for LCBs, ASEAN+3 has established and funded the operations of www.asianbondsonline.adb.org and the publication of the Asian Bond Monitor in order to provide information on the development of LCBMs in the region to market participants. A study on Broadening Investor Base for LCBMs in ASEAN+2 (Japan was excluded) was also undertaken to provide policy recommendations to member countries on measures to broaden investor base for LCBs to help minimize the impact of reversal of capital flows on member countries.

ASEAN+3 established the Asian Bond Market Forum (ABMF) in 2010 as a common platform to foster standardization of market practices and harmonization of regulations relating to cross-border bond transactions in the region. To provide information on market regulations and practices in 11 ASEAN+3 economies, a bond market guide is provided in www.asianbondsonline.adb.org. ABMF is also developing an ASEAN+3 Multi-currency Bond Issuance Framework, a common regional bond issuance program to allow qualified issuers from any country in ASEAN+3 to issue LCBs in any $A S E A N+3$ currency in the $A S E A N+3$ region. ABMF is also working toward streamlining bond transaction flows, including more simplified disclosure requirements. 


\section{APPENDIXES}

\section{Appendix 1: Methodology for Identifying Capital Flow Wave Episodes}

The methodology for identifying the episodes is adopted from the Capital Flow Waves: Surges, Stops, Flight, and Retrenchment paper by Forbes and Warnock (2011). The episodes are defined as follows:

(i) Surges: a sharp increase in gross capital inflows;

(ii) Stops: a sharp decrease in gross capital inflows;

(iii) Flight: a sharp increase in gross capital outflows; and

(iv) Retrenchment: a sharp decrease in gross capital outflows.

Indonesia, the Republic of Korea, the Philippines, and Thailand

\section{Surge Episodes}

FDI-led: Q4 2012

Equity securities-led: Q2-Q3 1999, Q1 2004, Q3 2009

Debt-led (excl. banking flows): Q1-Q3 2002, Q2 2007, Q4 2007

Banking flows-led: Q1 1999, Q4 2009-Q2 2010

\section{Stop Episodes}

\section{FDI-led: -}

Equity-led: Q4 2000, Q4 2004, Q4 2006-Q1 2007, Q1-Q3 2008, Q3-Q4 2011

Debt-led (excl. banking flows): Q1-Q3 1997, Q1-Q3 2001, Q1 2012

Banking flows-led: Q4 1996, Q4 1997-Q2 1998, Q4 2008-Q1 2009

\section{Flight Episodes}

FDI-led: -

Equity-led: Q2-Q4 2007

Debt-led (excl. banking flows): Q2 1999, Q4 2005, Q4 2009-Q2 2010

Banking flows-led: Q3 1999, Q4 2002-Q2 2003, Q3 2004, Q1-Q2 2006

\section{Retrenchment Episodes}

FDI-led: -

Equity-led: Q2 2008-Q1 2009

Debt-led (excl. banking flows): Q1-Q2 1998, Q1 2008

Banking flows-led: Q4 1996-Q1 1997, Q3-Q4 1998, Q1-Q2 2002, Q4 2004-Q2 2005 


\section{Appendix 2: Panel Regression Methodology: The Effects of the QE Tapering News and Events on Equities, Exchange Rates, and Bond Yields of Five Asian Economies ${ }^{6}$}

The expectations-driven panel regression was done to understand the effects of the QE tapering on:

(i) the growth of the nominal exchange rate and nominal effective exchange rate,

(ii) the growth of the S\&P Investable Funds Total Return, ${ }^{7}$ and

(iii) the change in 10-year country bond yields.

Five emerging Asian markets were chosen-India, Indonesia, Malaysia, the Philippines, and Thailand-because they were heavily affected by the QE and news or decisions concerning the QE tapering. The simple model used is based on Robin Koepke's (2013) paper written for the International Institute of Finance. The key explanatory variable representing the QE tapering is the expected US Fed

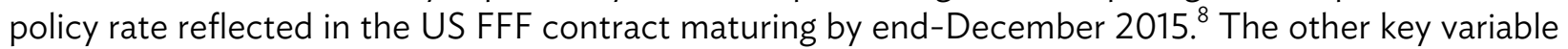
is "perceived global risk," as measured by the changes in the spread of BBB-rated US corporate bonds over the US 10-year treasury rate. ${ }^{9}$ The growth of industrial production in the PRC-lagged one period-was also included in the regression.

Country dummies were used in the fixed effect panel regressions. The model assumes there is a stronger slope coefficient for the key variable of expected FFF rate during the period from 23 May 2013 to 18 September 2013. Because the regressions use monthly data, the dummy "taper1" would include the months of June 2013 to September $2013 . .^{10}$

6 J. Villafuerte, J. Lim, and M. A. Cokee. Forthcoming. The Impact of US Federal Reserve Tapering on Selected Asian Economies and Related Issues. ADB Economics Working Paper Series.

7 The S\&P Investable Funds is a composite price index per country made up mostly of equities open to foreign investors.

8 The expected US Fed policy rate is computed as 100 minus the average daily US FFF contract price for the delivery month-for example, a 6.5\% rate equals a 93.50 contract price. It acts as a forecast of the average monthly level of the Federal funds rate. It is postulated that if the $\mathrm{QE}$ is expected to continue as is, there would be low expected future interest rates, and investors will have a stronger risk appetite to invest in emerging market portfolios. On the other hand, if the $Q E$ is expected to be tapered by significant amounts, there would be significantly higher future interest rates, and investors will reduce their risk appetite to invest in emerging market portfolios.

9 A BBB-rated corporation refers to a corporate entity seen to have adequately weakened during adverse economic conditions. Thus, the spread between this and the rate of the least risky bond-the US 10-year treasury note-is seen as a measure of the perceived risk to a medium investment-grade firm.

${ }^{10}$ A change in the dummy from May 2013 to September 2013 showed almost the same results as the regressions presented in the table. 


\section{Appendix 3: Methodology}

\section{Bivariate and Multivariate GARCH}

The methodology for identifying the episodes is adopted from The Threat of Financial Contagion to Emerging Asia's Local Bond Markets: Spillovers from Global Crises paper by Azis et al. (2013).

The paper employed multivariate Generalized Autoregressive Conditional Heteroskedastic (GARCH) models with a Baba-Engle-Kraft-Kroner specification to show significant shock and volatility spillovers from the US and the EU bond markets into Asian local currency bond markets. The analysis was extended to show indirect spillovers within domestic asset markets and across economies. Daily data was divided into three periods: (i) precrisis period (July 2005-August 2008), (ii) Lehman collapse period (September 2008-March 2009), and (iii) peak of eurozone debt crisis (September 2011-May 2012). Week-on-week returns on the 5-year US Treasury bond yields, 5-year German bund yields, 5-year EU composite government bond yields were used, US high-yield corporate bond yields (with a Baa rating from Moody's), and EU high-yield corporate bond yields (mainly finance sector bonds) were used to determine the direct transmission from advanced economies to the Asian economies' 5-year government bond yields. Asian economies include the PRC, Indonesia, the Republic of Korea, Malaysia, the Philippines, and Thailand. Domestic local bond, domestic equity, domestic currency, and domestic money markets were based on authors' calculations. 


\section{Appendix 4: Composition of Capital Flows (as shown in Figures 4 and 5)}

\begin{tabular}{ll}
\hline Cluster & Components \\
\hline Direct investment & FDI equity \\
& FDI debt \\
\hline Portfolio equity securities & Portfolio investment equity \\
\hline Debt & Portfolio investment debt \\
& Other investment - Currency and deposits in other sectors \\
& Other investment - Central bank loans \\
& Other investment - General government loans \\
& Other investment - Other sector loans \\
& Other investment - Trade credit \\
& Other investment - Other accounts of other sectors \\
& Other investment - Currency and deposits in deposit-taking corporations, excluding \\
& Central bank \\
Other investment - Deposits in deposit-taking corporation (excluding central bank) & loans \\
Other investment - Other accounts of banks
\end{tabular}

$\mathrm{FDI}=$ foreign direct investment.

Notes: Capital inflows refer to liability items. Capital outflows refer to asset items.

Source: IMF, International Financial Statistics (accessed 3 October 2014). 


\section{REFERENCES}

Aldaba, R. M., J. T. Yap, and P. A. Petri. 2009. The AEC and Investment and Capital Flows. In M.G. Plummer and S.Y. Chia, eds. Realizing the ASEAN Economic Community: A Comprehensive Assessment. Singapore: Institute of Southeast Asian Studies.

Asian Development Bank (ADB). 2008. Emerging Asian Regionalism: A Partnership for Shared Prosperity. Manila.

2010. Institutions for Regional Integration: Toward an Asian Economic Community. Manila.

Azis, I. J. 2014. Capital Markets as Financial Safety Nets. In Asian Capital Market Development and Integration: Challenges and Opportunities. Oxford University Press.

Azis, I. J., S. Mitra, and A. Baluga. 2013. Global Shock and Regional Spillovers. In R. Caruso, ed. Peace Economics, Peace Science and Public Policy. 19 (2). pp.183-211. Berlin: De Gruyter.

Azis, I. J., S. Mitra, A. Baluga, and R. Dime. 2013. The Threat of Financial Contagion to Emerging Asia's Local Bond Markets: Spillovers from Global Crises. ADB Working Paper Series on Regional Economic Integration No. 106. Manila: Asian Development Bank.

Brunschwig, S., B. Carrasco, T. Hayashi, and H. Mukhopadhyay. 2011. The Global Financial Crisis: Impact on Asia and Emerging Consensus. ADB South Asia Working Paper Series No. 3. Manila: Asian Development Bank.

Calvo, G. A., L. Leiderman, and C. M. Reinhart. 1994. The Capital Inflows Problem: Concepts and Issues. Contemporary Economic Policy XII. July.

-1996. Inflows of Capital to Developing Countries in the 1990s: Causes and Effects. Journal of Economic Perspectives. 10 (2). pp. 123-39.

Chinn, M. D. and H. Ito. 2008. A New Measure of Financial Openness. Journal of Comparative Policy Analysis. 10 (3). pp. 309-22.

Devlin, R., R. Ffrench-Davis, and S. Griffith Jones. 1995. Surges in Capital Flows and Development: An Overview of Policy Issues. In R. Ffrench-Davis and S. Griffith-Jones, eds. Coping with Capital Surges: The Return of Finance to Latin America. Ottawa: International Development Research Centre.

Fernandez-Arias, E. 1996. The New Wave of Capital Inflows: Push or Pull? Journal of Development Economics. 48 (2). pp. 389-418.

Fernandez-Arias, E. and P. Montiel 1996. The Surge in Capital Inflows to Developing Countries: An Analytical Overview. World Bank Economic Review No. 10. Washington, DC: World Bank.

Filardo, A. 2011. The Impact of the International Financial Crisis on Asia and the Pacific: Highlighting Monetary Policy Challenges from a Negative Asset Price Bubble Perspective. BIS Working Paper No. 356. Basel: Bank for International Settlements. 
Forbes, K. J. and F. E. Warnock. 2011. Capital Flow Waves: Surges, Stops, Flight, and Retrenchment. NBER Working Paper Series No. 17351. Cambridge, MA: National Bureau of Economic Research.

Gagnon, J. E. 2014. Currency and Maturity Mismatches in Asia. In Asian Capital Market Development and Integration: Challenges and Opportunities. Oxford: Oxford University Press.

Gallagher, K., S. Griffith-Jones, and J. A. Ocampo, eds. 2012. Regulating Global Capital Flows for LongRun Development. Pardee Center Task Force Report. Boston: Boston University.

Gochoco-Bautista, M. S. and C. Rhee. 2013. Capital Controls: A Pragmatic Proposal. ADB Economics Working Paper Series No. 337. Manila: Asian Development Bank.

Grenville, S. 2012. Rethinking Capital Flows for Emerging Asia. ADBI Working Paper Series No. 262. Tokyo: Asian Development Bank Institute.

Guitian, M. 1998, The Challenge of Managing Global Capital Flows. IMF Finance and Development. 35 (2). Washington, DC: International Monetary Fund.

International Monetary Fund (IMF). 2007. Managing Large Capital Inflows. Chapter 3 of World Economic Outlook. Washington, DC.

2011. Recent Experiences in Managing Capital Inflows-Cross-Cutting Themes and Possible Policy Framework. Strategy, Policy, and Review Department. Washington, DC: International Monetary Fund.

Ito, T. and Y. C. Park. 2004. Developing Asian Bond Markets: Challenges and Strategies. Canberra: Australian National University Asia Pacific Press.

Jeanne, O. 2012. Capital Account Policies and the Real Exchange Rate. PIIE Working Paper Series No. WP12-14. Washington, DC: Peterson Institute for International Economics.

2014. Capital Flow Management and Macroprudential Policies in Asia. In Asian Capital Market Development and Integration: Challenges and Opportunities. Oxford: Oxford University Press.

Kawai, M. and M. B. Lamberte. 2010. Managing Capital Flows: Emerging Asia's Experiences, Policy Issues and Challenges. In M. Kawai and M. B. Lamberte, eds. Managing Capital Flows: The Search for a Framework. Edward Elgar Publishing Limited.

Kawai, M. and P. J. Morgan. 2014. Regional Financial Regulation in Asia. ADBI Working Paper Series No. 460. Tokyo: Asian Development Bank Institute.

Kawai, M. and V. Pontines. 2014. The Renminbi and Exchange Rate Regimes in East Asia. ADBI Working Paper Series No. 484. Tokyo: Asian Development Bank Institute.

Kawai, M. and S. Takagi. 2010. A Survey of the Literature on Managing Capital Inflows. In M. Kawai and M. B. Lamberte, eds. Managing Capital Flows: The Search for a Framework. Edward Elgar Publishing Limited. 
Koepke, R. 2013. Quantifying the Fed's Impact on Capital Flows to EMs. IIF Research Note. Washington, DC: The Institute of International Finance.

Krugman, P. 1999. The Return of Depression Economics. Foreign Affairs. 78 (1). Council on Foreign Relations, Inc.

Lane, P. R. and G. M. Milesi-Ferretti. 2007. The External Wealth of Nations Mark II: Revised and Extended Estimates of Foreign Assets and Liabilities, 1970-2004. Journal of International Economics. No. 73 (2). pp. 223-50.

Levine, R. 1999. Foreign Bank Entry and Capital Control Liberalization: Effects on Growth and Stability. Mimeo. Minneapolis: University of Minnesota.

Levine, R. and M. Carkovic. 1999. Do Foreign Investment and Portfolio Inflows Accelerate Economic Growth? Manuscript.

Molnar, M., Y. Tateno, and A. Supornsinchai. 2013. Capital flows in Asia-Pacific: Controls, Bonanzas and Sudden Stops. OECD Development Centre Working Paper No. 320. Paris: Organisation for Economic Co-operation and Development.

Obstfeld, M. 2007. International Finance and Growth in Developing Countries: What Have We Learned? Commission on Growth and Development Working Paper No. 34. Washington, DC: World Bank.

Plummer, M. 2007. Completing the AIA: Road Traveled, Road Ahead. Project for the ASEAN Secretariat. East West Center.

Prasad, E., K. Rogoff, S. Wei, and M. Ayhan Rose. 2003. Effects of Financial Globalization on Developing Countries: Some Empirical Evidence. IMF Occasional Paper No. 220. Washington, DC: International Monetary Fund.

Radelet, S. and J. Sachs. 1999. What Have We Learned, So Far, From the Asian Financial Crisis? Harvard Institute for International Development. CAER Discussion Paper No. 37. Presented at the Annual Meetings of the American Economics Association.

Reisen, H. 1998. Net Capital Inflows: How Much to Accept, How Much to Resist? In R. Glick, ed. Managing Capital Flows and Exchange Rates: Perspectives from the Pacific Basin. Cambridge University Press.

Reisen, H. and M. Soto. 2001. Which Types of Capital Inflows Foster Developing-Country Growth? International Finance. 4 (1). pp. 1-14.

Rodrik, D. 1998. Who Needs Capital-Account Convertibility? In Should the IMF Pursue Capital-Account Convertibility? Essays in International Finance. No. 207. Princeton, New Jersey: International Finance Section, Princeton University.

Taylor, M. P. and L. Sarno. 1997. Capital Flows to Developing Countries: Long and Short-Term Determinants. World Bank Economic Review No. 11 (3). Washington, DC: World Bank. 
Thorbecke, W. 2012. The Contribution of the Yen Appreciation since 2007 to the Japanese Economic Debacle. CEPII Working Paper No. 31. Paris: Centre D'Etudes Prospectives et D'Information Internationales.

- 2013. Investigating the Effect of Exchange-Rate Changes in Japan, China, ${ }^{*}$ East Asia, and Europe. Vox. http://www.voxeu.org/article/investigating-effect-exchange-rate-changes-japanchina-east-asia-and-europe (accessed on 18 August 2013).

Villafuerte, J., J. Lim, and M. A. Cokee. Forthcoming. The Impact of US Federal Reserve Tapering on Selected Asian Economies and Related Issues.

Zhang, L. and E. Zoli. 2014. Leaning Against the Wind: Macroprudential Policy in Asia. IMF Working Paper No. WP/14/22. Washington, DC: International Monetary Fund.

* ADB recognizes “China” as the People's Republic of China. 


\section{Managing Capital Flows in Asia: An Overview of Key Issues}

Global capital flows into emerging markets, including those in Asia, continue to be volatile. These capital flows generate both benefits and costs. The latter are associated with episodes of currency and banking crises like the 1997 Asian financial crisis and the 2008 global financial and economic crisis. Recent data show that the main impact of capital flows on the economies of East Asia is reflected in real effective exchange rates, equity prices, and accumulation of foreign exchange reserves. In particular, econometric results show the strong linkages between the United States bond markets and those in Asia, particularly the adverse impact of quantitative easing tapering on Asian economies. These findings support the important role of macroprudential policy, which can be implemented in the context of regional cooperation in order to reduce negative spillovers across economies in Asia.

\section{About the Asian Development Bank}

ADB's vision is an Asia and Pacific region free of poverty. Its mission is to help its developing member countries reduce poverty and improve the quality of life of their people. Despite the region's many successes, it remains home to the majority of the world's poor. ADB is committed to reducing poverty through inclusive economic growth, environmentally sustainable growth, and regional integration.

Based in Manila, ADB is owned by 67 members, including 48 from the region. Its main instruments for helping its developing member countries are policy dialogue, loans, equity investments, guarantees, grants, and technical assistance. 